\title{
CROSS SECTORAL FDI SPILLOVERS AND THEIR IMPACT ON MANUFACTURING PRODUCTIVITY ${ }^{\dagger}$
}

\begin{abstract}
This paper explores the relationship between FDI spillovers and productivity in manufacturing firms in five European transition countries. The novelty of our approach lies in exploring different mechanisms of horizontal spillovers and disentangling the impact of backward and forward vertical spillovers from services and manufacturing sectors. We rely on firm level data obtained from the Amadeus database and annual input-output tables. The results from dynamic panel model estimations reveal that local manufacturing firms benefit from the presence of foreign firms in upstream services, especially in the knowledge intensive services, and in downstream manufacturing sector. Demonstration effect is found to be negatively associated with domestic firms' productivity, while worker mobility and increased competition appear to be the main channels of horizontal knowledge diffusion. The firms' productivity is also influenced positively by human capital and intangible assets. Finally, we show that the direction and intensity of both vertical and horizontal spillovers depend on the absorptive capacity of domestic firms.
\end{abstract}

Keywords: FDI, services, vertical linkages, productivity spillovers JEL classification: C23, D24, F23, O14

\footnotetext{
${ }^{\dagger}$ We thank to the three anonymous referees for their helpful comments and suggestions.
} 


\section{INTRODUCTION}

FDI is often recognised as a catalyst for economic development; hence countries of Central and Eastern Europe have put considerable effort in attracting FDI through financial, fiscal and/or other incentives (OECD, 2005; Jindra and Rojec, 2014). The incentives offered to multinational corporations (MNCs) are based on the premise that FDI makes important contributions to economic development through either voluntary or involuntary knowledge transfer to local firms within and across industries, resulting in productivity improvements (Caves, 1974; Markusen and Venables, 1999; Blomström and Kokko, 2001; Javorcik, 2004; Hallin and Holmstrom-Lind, 2012). However, the empirical evidence has been rather inconclusive, with the estimated impact varying from positive for backward linkages to insignificant or even negative for horizontal and forward spillovers (Görg and Greenaway, 2004; Havránek and Iršová, 2011; Iršová and Havránek, 2013). Several reasons have been put forward to explain this ambiguity: the measurement of FDI spillovers (Ben Hamida and Gugler, 2009; Barbosa and Eiriz, 2009; Barrios et al., 2011; Driffield and Jindra, 2012), empirical methodologies employed (Görg and Strobl, 2001), the heterogeneity of domestic and foreign firms in terms of absorptive capacity and potential for spillovers (Blalock and Simon, 2009, Damijan et al., 2013: Javorcik and Spatareanu, 2011; Ha and Giroud, 2015), the difficulty of disentangling unintentional knowledge spillovers from intentional knowledge diffusion (Smeets, 2008), and competition effects (Garcia et al., 2013).

Although a great deal of research has been devoted to understanding of FDI spillovers, some significant knowledge gaps remain. Most of the existing empirical literature has treated FDI spillovers as a black box and has settled so far to identify an overall net effect. Therefore, implications of the existing empirical studies for policy makers are not well understood due to a plethora of different results. In this paper we aim to disentangle the role of different spillover channels. To this end, we extend the traditional empirical framework by including different channels of horizontal spillovers and by exploring the role of services that might be responsible for significant forward spillovers due to their strong orientation towards the domestic market (Javorcik, 2007). Contrary to previous studies which limited FDI spillover analysis to either backward manufacturing (Blalock and Gertler, 2008; Damijan et al., 2013; Merlevede et al., 2014) or forward services linkages (Arnold et al., 2011, Fernandes and Paunov, 2012) we consider both sectors. 
FDI in services now accounts for almost 65 per cent of the total worldwide inward FDI stock (UNCTAD, 2014). Despite the broad consensus that the growth of services is crucial for economic growth and the development of other sectors (Francois, 1990; Eschenbach and Hoekman, 2006), little emphasis has been put on foreign firms in services. In addition, although the increasing role of services in economic output, employment and production processes at different levels of the value chain has been acknowledged (Hoekman and Mattoo, 2008; UNCTAD, 2008), spillovers from service sector firms to manufacturing customers and suppliers have been, with few exceptions, neglected (e.g. Miozzo and Grimshaw, 2008; Miozzo et al., 2012; Arnold et al., 2011; Fernandes and Paunov, 2012; Mariotti et al., 2013; Mariotti et al., 2015).

There are several reasons why FDI in services may have beneficial effects on domestic firms' productivity. First, given the limited scope for services trade, it is assumed that opening services to FDI brings advanced technology, know-how and other advanced inputs that may improve the performance of downstream domestic firms more directly than is the case of physical intermediate inputs which may be imported (UNCTAD, 2004; Kox and Rubalcaba, 2007). Moreover, many of the skills acquired by employees working for MNCs in services may be directly transferable to other sectors in the economy (Javorcik, 2007). Second, services are also direct inputs in the production function (Antonelli, 1999) and determine the productivity of factors of production, thus acting as a strong determinant of the competitiveness, innovation and growth (Guerrieri et al., 2005; Hoekman and Mattoo, 2008; François and Worz, 2008). Third, knowledge intensive services (KIS) may particularly have positive spillover effects on other industries if MNCs are not able to fully internalize the market for technology (Griliches, 1992; Camacho and Rodriguez, 2007; Arnold et al., 2011; Mariotti et al. 2013; Mariotti et al., 2015).

CEEC offer an interesting case for the analysis of FDI spillovers due to the massive expansion of the service sector - which played a minor role under socialism (Gabrisch and Hölscher 2006) - and the recent increase in FDI in services that is particularly relevant for increased efficiency, competition and quality of their service sector. Furthermore, governments of these countries invested significant resources in attracting MNCs (Jindra and Rojec, 2014). However, to date there has been no systematic investigation of the potential benefits of FDI in services on the productivity of manufacturing firms in these countries. Hence, this study aims to inform policy makers about productivity implications of FDI so that they can identify the industries that provide the largest potential for technology spillovers and adjust their investment incentives accordingly. It also provides important information for the management of domestic firms - that in order to benefit 
from FDI spillovers, they need to invest and improve the quality of their human resources and intangible assets.

We contribute to the existing literature in several ways. First, we argue that prevailing measurement of vertical linkages does not allow proper identification of entire spillover benefits as it fails to differentiate between the channels through which spillovers occur. This is, to our best knowledge, the first study that investigates the spillover effects of foreign firms on the total factor productivity of local manufacturing firms by using four measures of vertical FDI spillovers: two related to backward linkages and two to forward linkages, each arising from manufacturing and service sectors, respectively. This enables us to shed more light on the customer-supplier relationship between domestic and foreign firms in two main sectors of the economy. Second, drawing on the notion of absorptive capacity (Cohen and Levinthal, 1990; George and Zahra, 2002; Narula and Marin, 2003), which highlights that ability of local firms to absorb the external knowledge depends on the interaction between the mechanisms by which they occur and the existing absorptive capacity (Blalock and Simon, 2009; Sanchez-Sellero et al., 2014), we evaluate the moderating role of domestic firms' investment in intangible assets and human capital. By using interaction terms between foreign presence and human capital, we explore the additional channel of horizontal spillovers related to worker mobility. Third, we investigate the heterogeneity of forward linkages in services which depends on the knowledge intensity of the service sector.

The analysis is based on firm level data in five small transition economies ${ }^{1}$ (the Czech Republic, Estonia, Hungary, Slovakia and Slovenia) for the period between 2002 and 2010. These countries are characterised by strong penetration of foreign investment. Unlike other empirical studies, we use annual input-output tables for the calculation of spillover measures thus relaxing the restrictive assumption of fixed customer-supplier relationships at industry level. Our empirical strategy is based on a two-stage approach. In the first stage, we estimate firms' total factor productivity (TFP) using a semi-parametric method. In the second stage, we explore productivity spillovers using a dynamic model that tackles the problem of endogeneity.

The next section explains the motivation for investigating FDI spillovers in selected Central and Eastern Europe Countries (CEECs) and justifies our focus on vertical spillovers from FDI in

\footnotetext{
${ }^{1}$ There are a few other small transition economies in Central and Eastern Europe, notably the Baltic states, but the unavailability of full data for these countries restricts the analysis to the five CEE countries. The unavailability of inputoutput tables for Croatia meant that this country had to be dropped too.
} 
services. In section 3, we review the current literature and relevant theoretical background, and formulate our hypotheses. Section 4 explains the variables used, the data and the empirical methodology, and presents the baseline empirical model. Section 5 details empirical findings and discusses the results of alternative model specifications. The last section contains concluding remarks including policy implications and suggestions for further research.

\section{SERVICES FDI IN CEEC}

At the beginning of the 1990s, the CEECs went through a process of transition from centrally planned to market oriented economies. FDI was one of the main drivers of this process, and constituted the main element of industrial policy in these countries (Myant and Drahokoupil, 2010). The reliance on FDI was especially pronounced in small CEECs (except Slovenia) where it was expected to bring the necessary capital, technology and know-how in an environment characterized by low investment and savings. Although foreign investors had to deal with political and economic instability, weak institutional framework and low quality of infrastructure, they were attracted by huge unsaturated market (e.g. Poland), skilled but cheap labour and privatization opportunities. MNCs successfully restructured the companies they acquired (Djankov and Murrell, 2002), increased their efficiency (Jindra, 2006) and international competitiveness (Rugraff, 2006). By early 2000s the increased integration of CEECs in Global Value Chains, especially into German automotive supply chain, led to increased embeddedness of foreign subsidiaries into local economies and promoted the upgrading of domestic manufacturing suppliers through the creation of backward linkages (Jindra et al., 2009) and spillovers associated with it (Damijan et al., 2013; Merlevede et al., 2014).

In the first decade of transition, foreign service providers undertook mainly horizontal demand-led investments (Hardy et al., 2011) that generally involved joint ventures or takeovers of domestic firms to draw on domestic firms' expertise and access to their clients (Dicken, 2003; Dossani and Kenney, 2007). However, with increased fragmentation and reallocation of production activities, many Western MNCs have moved their service operations to CEECs, the bulk of it going to the Czech Republic, Hungary and Poland to achieve cost efficiencies (Sass, 2008). These countries emerged as locations for outsourcing and offshoring of specific business functions (Fillipov and Kalotay, 2009). 
Given the far reaching organizational changes in MNCs over the past decade, embedding domestic firms into production networks and fostering network-type linkages that are based on knowledge sharing is high on policy agenda of many governments in CEECs. In this context, services FDI offer opportunities for local firms to participate in the international division of labour, building upon their advantages such as highly skilled labour, ICT infrastructure and cultural proximity to Western Europe (i.e. the main investor). Although services constitute the majority of foreign firms in the CEECs and might be responsible for significant forward spillovers, so far, the impact of FDI in the service sector has been mainly investigated by case studies showing limited backward and forward linkages (Capik and Drahokoupil, 2011; Hardy et al., 2011) while implications for manufacturing firms' productivity have not been investigated except in very limited cases (Arnold et al., 2011). This study aims to fill this gap by differentiating between the vertical spillovers from the manufacturing and services.

\section{MNCS AND POTENTIAL SPILLOVERS}

\subsection{INTRA- INDUSTRY SPILLOVERS}

The most common assumption in FDI theory and new trade theory is that MNCs are the most productive firms and possess specific advantages that enable them to reap the benefits of operating in foreign countries and transfer technology across borders (Dunning and Lundan, 2008; Helpman et al., 2004; Antras and Yeaple, 2013). Given the technological sophistication of MNCs and their productivity advantage, a large volume of literature has developed to explain how FDI spillovers occur. Horizontal spillovers occur mainly through unintentional knowledge diffusion due to market failure (non-excludable and non-rival nature of knowledge) and therefore constitute an externality (Arrow, 1962; Hallin and Holmstrom-Lind, 2012). This unintentional knowledge diffusion could occur via different channels. One of these is the demonstration effects, which occur through imitation and reverse engineering of MNCs' ownership advantages, such as their know-how, and organizational and marketing practices (Kouizumi and Kopecky, 1977; Findlay, 1978). Worker mobility may be another source of knowledge spillovers as the MNCs are likely to provide host country workforce with more training, education and valuable work experience (Fosfuri et al., 2001; Glass and Saggi, 2002; Smeets, 2008; Markusen and Trofimenko, 2009). 
Another strand of the literature emphasizes the endogenous nature of spillovers generated by competition between foreign and local firms (Wang and Blomström, 1992). The effects on local firms' behaviour are mainly pecuniary in nature. Foreign firms paying higher wages and offering other benefits may raise labour costs for local firms who want to keep their most valuable employees (Spencer, 2008). This increased competition may put downward pressure on prices leading to lower profitability and hence crowding out of local firms (Aitken and Harrison, 1999). Increased competition, however, may also have indirect knowledge effects by providing incentives to domestic firms to introduce stricter or more cost conscious management, develop new technology and encourage more efficient allocation of resources resulting in increased productivity (Blomström and Kokko, 1998). However, this cannot be considered as pure "not paid for" externality as domestic firms need to invest in their R\&D, introduce organizational and managerial innovations and upgrade the skills of their employees which ultimately result in adoption and development costs (Zanfei, 2012).

Empirical studies find the effect of FDI horizontal spillovers on productivity of domestic firms in CEECs to be mostly insignificant or even negative (Djankov and Hoekman, 2000; Konings, 2001; Kolasa, 2008: Gersl et al., 2008; Damijan et al., 2013). These results are conditional on the measurement of horizontal spillovers. For example, Javorcik and Spatareanu (2008) use the share of foreign firm sales in total industry sales and find negative effects due to strong competition, while Schoors and Merlevede (2007) highlight a positive effect due to labour turnover. As emphasized by Ben Hamida and Gugler (2009), the ambiguity of empirical results is closely related to inability of theoretical and empirical models to provide a complete picture of the diverse channels and mechanisms through which technology is transmitted. In fact, the commonly used horizontal spillover effects measured by the share of foreign presence in the corresponding industry (e.g. share of foreign firms in total industry employment or sales) only capture the overall demonstration effects while it can partially contain competitive and/or worker mobility effects (Ben Hamida, 2013). To shed more light on the black box of different FDI spillovers mechanisms with potentially opposite effects, Ben Hamida and Gugler (2009) suggest to include additional control variables for each spillover mechanism.

With the above discussion in mind, this paper aims to test the following hypotheses:

H1a: The presence of MNCs in manufacturing is positively related to the productivity of domestic manufacturing firms in the same sector 
H1b: The presence of MNCs in manufacturing is negatively related to the productivity of domestic manufacturing firms in the same sector

We expect $\mathrm{HIa}$ to hold if the positive demonstration and worker mobility effects prevail over the negative competition effect and $H 1 b$ to hold when the MNCs are able to prevent the leakage of knowledge and technologies to local counterparts and exploit their superior technology and market power to force local competitors to reduce their output.

\subsection{INTER-INDUSTRY SPILLOVERS}

Vertical spillovers arise through customer-supplier relationship between the domestic and foreign firms. MNCs have an incentive to minimize technological leakages to their direct competitors but have a strong incentive to improve the productivity of their suppliers as improved input quality strengthens their competitive position in global markets (Alfaro and Rodriguez, 2004: Javorcik, 2004; Alcacer and Oxley, 2014). Backward spillovers occur when domestic suppliers experience productivity improvements through direct linkages and deliberate knowledge transfer from foreign customers (Giroud et al., 2012). By engaging in cooperation with MNCs, domestic suppliers are expected to benefit from inter-firm exchange of technical and managerial knowledge, assistance on product design, quality control and inventory management as well as financial and procurement assistance (Giroud, 2007; Zanfei, 2012). Even domestic firms which do not have a contractual relationship with foreign firms may benefit from spillovers through incentives to improve the quality of their products or scale economies arising from greater demand for domestic inputs (Javorcik, 2004; Newman et al., 2015). However, increased competition from abroad may result in negative backward spillovers if foreign firms rely on imported inputs.

Forward spillovers through direct linkages occur when foreign suppliers provide knowledge embodied in products, processes and technologies to domestic customers (Jindra et al., 2009). Domestic downstream firms may also benefit from indirect spillovers if the increased competition from foreign firms lead to better quality of inputs and lower prices (Rodriguez-Clare, 1996; Markusen, and Venables, 1999). However, opposite effects may also be observed if foreign firms capture a higher market share leaving domestic customers with fewer alternatives, hence higher input prices. 
Spillovers from vertical linkages and corresponding productivity improvements occur either through voluntary knowledge transfer or through externalities in the form of increased demand for intermediate inputs (Giroud, 2012; Newman et al. 2015). Our dataset does not allow us to separate the effects of these two mechanisms. ${ }^{2}$ Therefore, our estimations capture the combined effects of pure "not paid for" technological externalities that shift firm's production function and pecuniary externalities that arise from competition effects and changes in input prices. Positive spillovers will be observed if pecuniary and technological externalities outweigh negative competition effects.

The above discussion points to a further hypothesis about linkages which is tested in this paper: H2: The presence of manufacturing MNCs creates positive backward spillovers to domestic manufacturing suppliers

H3: The presence of manufacturing MNCs creates positive forward spillovers to domestic manufacturing customers

\subsection{Spillovers From the Service Sector}

There are several reasons why FDI in services may have beneficial effects on domestic manufacturing firms' productivity. It has been argued that the liberalization and deregulation of services has brought substantial benefits to the manufacturing sector in the form of cost reduction, increased variety, availability and better quality of inputs (Oulton, 2001; Barone and Cingano, 2011; Bourlès et al. 2013; Arnold et al., 2011; Fernandes and Paunov, 2012). Apart from increased competition which results in lower input prices, the superior technology of MNCs (Mirodout, 2006; Miozzo and Grimshaw, 2008) and the high quality of their services are expected to increase the TFP and innovative capability of domestic firms (Kox and Rubalcaba, 2007; Mas-Verdu et al. 2011; Evangelista et al., 2013). Although, theory provides compelling arguments for the importance of services inputs for manufacturing, firm level evidence on the effect of forward and backward spillovers from services are still relatively scarce.

Arnold et al. (2011) analyse the impact of privatization, services liberalization, FDI penetration and the extent of competition in the services sector in the Czech Republic and find a strong positive association between services FDI and productivity of downstream manufacturing firms. Similar

\footnotetext{
${ }^{2}$ In the estimation of FDI productivity spillovers researchers, with a few exceptions (Newman et al., 2015), have been unable to separate the effects of intentional knowledge transfer from the knowledge spillovers (Smeets, 2008).
} 
results are obtained by Fernandes and Paunov (2012) using Chilean data. Mariotti et al. (2013) investigate the impact of services MNCs on both upstream and downstream manufacturing firms in Italy. Their results point to both backward and forward linkage effects, the latter being the main channel for the transmission of knowledge to manufacturing firms.

The capacity of services MNCs to affect the productivity and efficiency of client firms is highly differentiated by the degree of tacit and codified knowledge (Consoli and Elche-Hortelano, 2010; Miles, 2005; Kox and Rubalcaba, 2007; Shearmur and Doloreux, 2008), and qualitative and innovative content of specific services provided to customers (Evangelista et al., 2013). Knowledge being their essential asset (Miles, 1994) - thus making spatial proximity a fundamental attribute (Landry et al., 2012; Doloreaux and Sharmour, 2012) - KIS can supply various types of inputs at varying levels of complexity, bring new knowledge, provide solutions and add or compensate for missing internal capacity by generating personalized solutions aimed at specific user's needs (den Hertog, 2000; Tether and Hipp, 2002). Hence, the interaction with KIS may support and/or improve the domestic customers' innovation and organizational processes (Ripolles-Melia et al., 2010; Shearmur et al., 2015).

Based on the discussion above, the following hypotheses will be tested in this paper:

H4: The presence of services MNCs creates positive forward spillovers to manufacturing customers H5: The effects of forward linkages from services on downstream manufacturing firms is reinforced by the presence of MNCs in knowledge intensive services (KIS)

\section{EMPIRICAL STRATEGY}

\subsection{ESTIMATING FIRMS' PRODUCTIVITY}

The literature on the estimation of TFP at firm level has developed significantly over the past years. The original approach of estimating a Cobb-Douglas production function using OLS method was criticised for producing biased results due to the endogeneity of factor inputs and the unobserved productivity (Marschak and Andrews, 1944). In response to this, Olley and Pakes (1996), Levinsohn-Petrin (2003) and Ackerberg et al. (2006) developed a semi-parametric estimator that imposes a certain structure on firm behaviour and timing of factor inputs. The TFP estimates in this study are obtained using Wooldridge (2009) estimator as implemented by Petrin et al. (2011) and 
Petrin and Levinsohn $(2012)^{3}$. This approach is in several ways superior to Olley and Pakes (OP) and Levinsohn and Petrin (LP) estimators. ${ }^{4}$

Production functions are estimated for each country-industry combination identified by 2-digit NACE Rev. 1.1 classification to account for the heterogeneity arising from different production technologies, quality and intensity of inputs. ${ }^{5}$ Output is measured by the value added, labour by the number of employees, capital by the book value of tangible fixed assets, and intermediate inputs are proxied by the cost of materials. Monetary values are deflated using industry price indices obtained from the OECD STAN database.

\subsection{MEASUREMENT OF FDI SPILLOVER VARIABLES}

To estimate the spillovers from the operation of foreign firms in manufacturing or services on the productivity of manufacturing firms, we define three types and measures of spillovers: horizontal, vertical backward and vertical forward. The last two are further divided into spillovers from MNCs in the manufacturing and service sectors. Horizontal spillovers for each industry-year are defined as: ${ }^{6}$

$$
\text { Horizontal }_{j t}=\frac{\sum_{i \epsilon j}\left(\text { Foreign }_{i t} * Y_{i t}\right)}{\sum_{i \epsilon j} Y_{i t}}
$$

where $Y_{i t}$ is the output (measured as revenue) produced by firm $i$ in industry $j$ in year $t$ and Foreign is a dummy variable taking value of one if the sum of shares of foreign investors in firm $i$ is at least $10 \%$ of the firm's equity or higher and zero otherwise. The horizontal measure captures the share of foreign firms in the total output produced in industry $j$ in time $t$. It is mainly a measure of demonstration effects. To differentiate between different spillover mechanisms, we additionally include two control variables: (i) interaction of foreign presence within the industry with the level

\footnotetext{
${ }^{3}$ We have also employed alternative estimators (OLS, system-GMM and Levinsohn-Petrin) for robustness checks. The results of Cobb-Douglas production function estimates for each industry and country as well as correlation coefficients of TFP estimates between different approaches can be found in Tables A1 and A2 in Appendix. Results are in most cases comparable with those obtained by the Wooldridge methodology.

4 First, it allows for simultaneous determination of factor inputs and technical efficiency. Second, it provides efficient standard errors robust to both heteroscedasticity and autocorrelation which is not the case with other structural estimators that rely on bootstrapped standard errors. Third, it is robust to Ackerberg et al. (2006) critique where labour may be unidentified in the first stage of the LP estimator.

${ }^{5}$ In order to satisfy the requirement of at least 50 observations per industry (Gal, 2013), some industries in each country have been merged based on the grouping used in the WIOD database.

${ }^{6}$ When calculating horizontal spillover measure, we included all firms in the database regardless of whether or not they were included in the TFP estimation (some firms were excluded from the latter because the data for some of the production function variables were missing).
} 
of human capital; this serves as a proxy for labour mobility (ii) Herfindahl index as measurement for competition effects.

For the calculation of the vertical forward and backward spillovers, we follow the standard practice in the literature (Javorcik, 2004; Arnold et al., 2011) and approximate the inter-industry linkages by using each country's input-output tables obtained from the World Input-Output Database (WIOD). Information on 2-digit inter-industry sourcing are then combined with information from the Amadeus database. WIOD provides annual input-output tables, allowing us to integrate into the analysis the most recent developments in firm behaviour, i.e. the increased splintering of the value chain as well as the intensified outsourcing and offshoring behaviour (Baldwin and Lopez-Gonzalez, 2013). This brings about a significant improvement over previous studies in measuring interindustry sourcing behaviour.

The vertical backward and forward spillovers from the presence of foreign firms are defined as:

$$
\begin{aligned}
& \text { Backward }_{j t}=\sum_{k=1}^{K} \alpha_{j k t} \text { Horizontal }_{k t} \\
& \text { Forward }_{j t}=\sum_{l=1}^{L} \gamma_{l j t} \text { Horizontal }_{l t}
\end{aligned}
$$

where Backward $_{j t}$ (Forward $_{j t}$ ) measures the spillover effects from the MNCs to the upstream (downstream) domestic manufacturing firms. $\alpha_{j k t}$ is the share of manufacturing industry $j$ 's output supplied to industry $k$ while $\gamma_{l j t}$ is the share of total inputs sourced from sector $l$ to manufacturing sector $j$. Horizontal is the horizontal spillover measure given above. The technical coefficients $\alpha_{j k t}$ and $\gamma_{l j t}$ are obtained from the annual I-O tables while the horizontal spillovers are calculated using firm level information from the Amadeus database. ${ }^{7}$ Each of these spillover measures is calculated for manufacturing and services separately. Equations 2 and 3 imply that the stronger the inter-industry linkages or the higher the presence of foreign firms in the industry, the higher the spillover measure will be.

\footnotetext{
7 Javorcik (2004) suggests to exclude the inputs supplied within the same industry while computing the technical coefficients $\alpha_{j k t}$ and $\gamma_{j l t}$. We depart from this approach due to relatively high aggregation of industries in WIOD; the exclusion of inputs supplied within the same 2-digit industry would cause productivity spillovers occurring at lower levels of aggregation to be captured by horizontal spillovers and lead to underestimation of vertical spillovers (Barbosa and Eiriz, 2009).
} 


\subsection{EMPIRICAL MODEL}

The relationship between FDI and productivity is analysed by using a system-GMM approach (Arellano and Bond 1991; Arellano and Bover 1995; Blundell and Bond 1998) where FDI spillovers measures are treated as endogenous. ${ }^{8}$ There are two main reasons for the choice of this method. First, since FDI is more likely to go to industries or regions that exhibit higher productivity ex ante, a positive correlation between FDI and productivity of domestic firms might simply reflect the location decision by foreign investors rather than positive spillover effects (Hale and Long, 2011). In addition, large and more productive manufacturing firms may lobby for the liberalization of particular service subsectors, thus generating a reverse causality situation and an upward bias in the coefficients of vertical linkages from services (Shepotylo and Vakhitov, 2015). Also, strong productivity growth of manufacturing firms may have attracted MNCs due to strong demand. The second reason is the dynamic nature of TFP, a static specification would be inappropriate given the autoregressive structure assumed in semi-parametric estimators.

The baseline model has the following form:

$$
\ln T F P_{i j t}=\beta_{0}+\beta_{1} \ln \left(T F P_{i j, t-1}\right)+\beta_{2} M N C_{j t}+\beta_{3} D F_{i t}+\beta_{4} I N D_{j t}+\theta_{j}+\theta_{r}+\theta_{t}+\varepsilon_{i j t}
$$

where $\ln T F P_{i j t}$ is the logarithm of total factor productivity of firm $i$ in industry $j$ at time $t, M N C_{j, t}$ is a vector of spillover measures as defined above, $D F_{i t}$ is a vector of firm level determinants of TFP, and $I N D_{j t}$ is a vector of variables controlling for competition and demand effects in industry $j$. Finally, $\theta_{j}, \theta_{r}, \theta_{t}$ denote industry (NACE 1.1), region (NUTS3) and time dummies to control for the unobserved effects such as the economy-wide technological progress, macro productivity shocks, changes in specialization of certain industries and agglomeration economies that may also affect firm productivity.

The firm level controls include two variables to capture firm's absorptive capacity. The first one is the firm's employees' skill level proxied by the average labour cost, i.e. the ratio of total labour cost to the number of employees in the firm (Wagner, 2012). The second variable is the firm's endowment of specific advantages proxied by the ratio of intangible assets to tangible fixed assets.

\footnotetext{
${ }^{8}$ The lagged dependent variable is treated as predetermined while variables measuring FDI spillovers (horizontal, backward and forward) are treated as endogenous and as such are instrumented with their own lags and lagged differences. The initial specifications included the minimum number of lags, i.e. one lag for levels and differences in case of lagged dependent variable and two lags for FDI spillover variables (Roodman, 2009). However, in certain cases model diagnostics with minimum number of lags were not satisfied and therefore the instrument matrix included higher order lags (three or four) of the regressors.
} 
Both variables are measured in logarithms. Additionally, we control for firm's age in years and size measured by firm's total assets in logarithms. These two variables are included in quadratic form to control for possible nonlinear effects.

As for industry controls, Herfindahl-Hirschman concentration index is used to account for the intensity of competition. It is defined as the sum of squares of the sales shares of all firms in industry $j$ at time $t$. Hence a higher index value, i.e. a value close to 1 , implies lower competition. Inclusion of the concentration index is particularly important for the measurement of horizontal and forward spillovers as it isolates the effects of increased competition from knowledge spillovers (Javorcik, 2004). A negative coefficient for this index is expected when increased competition (i.e. lower index value) is associated with productivity increases.

Demand variable, on the other hand, controls for increased demand in downstream sectors due to entry of MNCs:

$$
\operatorname{Demand}_{j t}=\sum_{k=1}^{K} \alpha_{j k t} Y_{k t}
$$

where $\alpha_{j k t}$ represents the share of industry j's output needed to produce one unit of industry $k$ 's output at time $t$ and $Y_{k t}$ is the total real output of industry $k$ derived from the input-output tables (WIOD). Increased demand may induce scale economies which may be translated into higher TFP of local supplying firms.

\subsection{DATA AND DESCRIPTIVE STATISTICS}

Central to the empirical analysis is the firm level Amadeus database provided by Bureau van Dijk $(B v D)$ which contains the balance sheet and income statement information for a very large number of firms in the countries under consideration over the period 2002-2010. ${ }^{9}$ Amadeus also provides other firm level information relevant for our analysis such as detailed ownership information, year of incorporation, employment, location of the firm, its economic activity, etc. We use several indicators to separate foreign and domestic firms. These are shareholders' names, their percentage share in equity and their country of origin. The most recent version of Amadeus enables to track ownership changes across years. This is a significant improvement over previous studies which distinguish domestic and foreign firms according to the information for the last year of the period of analysis, assuming that a firm was domestic or foreign throughout the period of analysis - clearly

\footnotetext{
${ }^{9}$ Eapen (2013) suggests that in incomplete datasets such as Amadeus the effects of FDI productivity spillovers may be overestimated due to selection effects if one excludes small firms from the sample. Hence, the data is taken from the "full" version of Amadeus database with no size threshold.
} 
ignoring the fact that the ownership of firms changed regularly in the transition period. A firm is defined as foreign if the foreign shareholders directly own at least 10 per cent of its equity (IMF, 2009).

Bartelsman et al. (2009) point out that cross-country comparison of firm dynamics is hampered by definitional problems as well as measurement problems due to differences in coverage, unit of observation, classification of activity and data quality. This caveat also applies to the Amadeus database as it relies on national data sources, which are subject to change over time. To illustrate the coverage of Amadeus database we compare the original augmented version to Eurostat Structural Business Surveys (SBS). The validation consists of calculating employment, turnover and variables used to estimate TFP averaged over industry-time level by country. The results are reported in Table A3 in Appendix. Averaged over countries, our dataset covers at least 47 per cent of employment and 63 per cent of total turnover in the economy. However, Amadeus lacks representativeness in terms of size because non-reporting firms are typically the smallest ones. The bias towards larger firms in Amadeus is also confirmed in our case, in particular for Hungary - as shown in Table A4 in Appendix. Although the sample of firms in Amadeus may not be representative of entire population of firms for which TFP can be estimated, we still obtain representativeness that is comparable to the CompNet database (CompNet Task Force 2014), which is currently the most representative dataset that allows cross-country comparison of firm productivity, but is currently publicly unavailable at firm level. The Amadeus database is the only publicly available database which allow researchers to utilize cross-country firm level data. Despite its disadvantages, it has been extensively used in estimating TFP of firms (Damijan et al., 2013; Sanfilippo, 2015; Smeets and de Vaal, 2016) and exploring the location of foreign affiliates across EU regions (Casi and Resmini, 2014).

After cleaning the dataset for productivity estimation, the final sample contains an unbalanced panel of 20,050 domestic firms during the 2002-2010 period - 95,875 firm-year observations in 23 manufacturing industries (at 2 digit NACE, Rev. 1.1 classification). ${ }^{10}$ Table A5 in the Appendix presents the number of domestic firms' observations in each country used in the estimation of TFP classified per Eurostat classification of technology intensive industries. To construct the measures

\footnotetext{
${ }^{10}$ For the construction of TFP sample we need information on firms' sales, tangible fixed assets, number of employees and expenditure on materials. Firms with missing, negative or zero values for any of the variables of interest are dropped from the sample. We have also eliminated observations for which accounting rules are violated. In order to avoid the extreme effects of outliers and aberrant values due to typing errors during data entry we have computed output to labour ratio, value added to labour ratio, capital to output ratio, labour to output ratio and dropped firms below the 1st percentile and above 99th percentile of their respective distributions.
} 
of intra and inter-industry spillovers we rely on the information presented in Table A6 which shows the total number of foreign and domestic firms before data cleaning. Between 66 and 80 percent of total number of foreign firms are in services. A closer look reveals that most foreign firms operate in less knowledge and market knowledge intensive services while a relatively smaller proportion operate in manufacturing, mainly in medium high and medium low technology industries.

Table 1 presents summary statistics of variables used in the estimation of spillovers (Section 4). As can be seen, the share of foreign firms' output in manufacturing ranges from 3 to 35 percent in Slovenia and Estonia, respectively. These shares hide significant differences across different industries (Figure A1 in the Appendix) - 55 percent of total output in transport equipment is produced by foreign firms in comparison to only 13 percent in textile industry. The foreign presence is also significant in electrical and optical equipment industry, chemical industry, production of coke and fuels, non-metallic mineral products and rubber and plastics. A more detailed analysis of vertical linkages across industries and countries is provided in Figures A2 and A3 in the Appendix. In general, backward linkages from manufacturing and forward linkages from services provide the largest potential for knowledge transfer.

Table 1. Summary statistics

\begin{tabular}{lccccccccccc}
\hline & \multicolumn{1}{c}{ Czech Republic } & \multicolumn{2}{c}{ Estonia } & \multicolumn{2}{c}{ Hungary } & \multicolumn{2}{c}{ Slovakia } & \multicolumn{2}{c}{ Slovenia } \\
\hline Variable & Mean & S.D. & Mean & S.D. & Mean & S.D. & Mean & S.D. & Mean & S.D. \\
\hline In TFP & 3.51 & 0.99 & 2.70 & 0.81 & 4.17 & 1.02 & 3.34 & 0.97 & 3.87 & 0.86 \\
Horizontal & 0.30 & 0.17 & 0.36 & 0.17 & 0.23 & 0.15 & 0.25 & 0.22 & 0.03 & 0.10 \\
Manufacturing & 0.13 & 0.08 & 0.10 & 0.06 & 0.12 & 0.07 & 0.13 & 0.09 & 0.05 & 0.04 \\
backward & 0.07 & 0.05 & 0.05 & 0.03 & 0.07 & 0.04 & 0.05 & 0.04 & 0.01 & 0.01 \\
Manufacturing forward & 0.04 & 0.02 & 0.07 & 0.03 & 0.03 & 0.01 & 0.04 & 0.02 & 0.02 & 0.01 \\
Services backward & 0.08 & 0.03 & 0.13 & 0.06 & 0.08 & 0.02 & 0.08 & 0.04 & 0.05 & 0.03 \\
Services forward & 0.03 & 0.01 & 0.09 & 0.04 & 0.04 & 0.01 & 0.03 & 0.02 & 0.04 & 0.03 \\
Services LKIS & 0.03 & 0.01 & 0.03 & 0.02 & 0.02 & 0.01 & 0.02 & 0.01 & 0.01 & 0.01 \\
Services KIS & -4.70 & 1.99 & -4.20 & 1.99 & -4.77 & 2.04 & -5.19 & 1.89 & -4.54 & 1.95 \\
ln Intangibles & 2.19 & 0.59 & 1.75 & 0.69 & 2.47 & 0.49 & 2.16 & 0.75 & 2.75 & 0.38 \\
In Human capital & 9.86 & 5.06 & 8.75 & 7.30 & 12.17 & 5.21 & 9.73 & 6.61 & 11.49 & 6.54 \\
Age & 122.89 & 143.22 & 129.71 & 445.96 & 175.30 & 221.41 & 138.29 & 319.58 & 174.75 & 225.19 \\
Age squared & 6.76 & 1.85 & 5.07 & 1.81 & 8.86 & 1.41 & 7.17 & 1.80 & 6.33 & 1.52 \\
In Size & 49.15 & 26.54 & 29.03 & 20.07 & 80.44 & 26.33 & 54.70 & 26.49 & 42.40 & 20.50 \\
ln Size squared & 0.03 & 0.06 & 0.08 & 0.08 & 0.11 & 0.14 & 0.08 & 0.10 & 0.16 & 0.15 \\
HHI & 8.14 & 1.01 & 5.75 & 0.97 & 8.60 & 0.82 & 8.56 & 1.29 & 6.98 & 0.89 \\
In Demand & & & & & & & & &
\end{tabular}




\section{EMPIRICAL FINDINGS AND DISCUSSION OF RESULTS}

This section presents the results of the model estimations. ${ }^{11}$ As system-GMM relies on internal instruments to deal with possible endogeneity, the Hansen $\mathbf{J}$ test of the validity of instruments together with autocorrelation test results are reported in the model diagnostics. In all models presented in the study, the Hansen $\mathrm{J}$ test cannot be rejected suggesting that employed instruments are satisfactory. Arellano and Bond test for autocorrelation confirms the absence of autocorrelation in second differences while rejecting the null hypothesis of no first order autocorrelation. Furthermore, the assumptions of no cross-sectional dependence and steady state are verified by the difference in Hansen $C$ tests, respectively, for the lagged dependent variable and the equation in levels, suggesting that the models are correctly specified. The correlation coefficient matrices (reported in Table A7) together with the Variance Inflation Factors (VIF) ${ }^{12}$ suggest that our results are not plagued by multicollinearity issues.

\subsection{BASELINE MODEL}

Table 2 presents the results for the baseline model. Since we control for competition effects, we can interpret our measure of horizontal spillovers as a combination of demonstration and worker mobility effects. The estimates for the horizontal spillovers point to negative effects of foreign firms' presence in the same industry, thus rejecting H1a and supporting H1b. These results confirm some of the previous findings which suggest that foreign firms have strong incentives to prevent the leakage of embodied knowledge and technologies to their domestic competitors (Javorcik, 2004; Iršová and Havránek, 2013; Newman et al., 2015). In addition, foreign firms engage in "cherry picking" of best employees on the market. As the supply of skilled labour is inelastic, this may put upward pressure on wages of skilled workers in industries dominated by foreign firms (Jude, 2016). This may in turn raise the production costs of domestic firms and result in reduced efficiency. As for the competition effects, increase in competition induces domestic firms to become more

\footnotetext{
11 Models are estimated separately for each country in the sample rather than pooling them together. This is mainly because this article aims to compare the FDI spillover effects in the selected countries rather than finding an overall average effect. Furthermore, as explained in the data section, Amadeus database relies on national sources, which may involve slight differences in the definition and measurement of variables in different countries. Besides, the estimations reveal heterogeneities among countries in the sample, supporting our preference for separate sample estimations. Finally, the effects of FDI across countries are likely to be different depending on host country characteristics. For example, across CEECs, growth and catch-up are determined by initial conditions, structural reforms, privatization and investment policies as well as the motives, structure and overall importance of FDI for economic upgrading.

12 VIF values for all variables are less than ten.
} 
productive in the Czech Republic while it impedes productivity improvement in Estonia; no significant evidence for either effect is found for the rest of the countries.

Table 2. System-GMM results of FDI productivity spillovers, baseline model

\begin{tabular}{|c|c|c|c|c|c|}
\hline VARIABLES & Czech Republic & Estonia & Hungary & Slovakia & Slovenia \\
\hline Lagged ln TFP & $\begin{array}{c}0.385 * * * \\
(0.022)\end{array}$ & $\begin{array}{c}0.267 * * * \\
(0.027)\end{array}$ & $\begin{array}{c}0.600 * * * \\
(0.114)\end{array}$ & $\begin{array}{c}0.385 * * * \\
(0.043)\end{array}$ & $\begin{array}{c}0.431 * * * \\
(0.057)\end{array}$ \\
\hline Horizontal & $\begin{array}{c}-0.167 * * \\
(0.083)\end{array}$ & $\begin{array}{c}-0.635 * * * \\
(0.158)\end{array}$ & $\begin{array}{c}-0.701 * * \\
(0.343)\end{array}$ & $\begin{array}{l}-0.383 * \\
(0.198)\end{array}$ & $\begin{array}{c}0.206 \\
(0.356)\end{array}$ \\
\hline Backward_manufacturing & $\begin{array}{c}1.740 * * * \\
(0.599)\end{array}$ & $\begin{array}{l}-0.597 * \\
(0.339)\end{array}$ & $\begin{array}{c}2.765 * * \\
(1.355)\end{array}$ & $\begin{array}{l}1.815^{*} \\
(1.100)\end{array}$ & $\begin{array}{l}1.841 * * \\
(0.933)\end{array}$ \\
\hline Forward_manufacturing & $\begin{array}{c}-2.573 * * * \\
(0.485)\end{array}$ & $\begin{array}{c}-1.331 * * * \\
(0.409)\end{array}$ & $\begin{array}{c}-3.082 * * \\
(1.373)\end{array}$ & $\begin{array}{l}-0.257 \\
(0.495)\end{array}$ & $\begin{array}{l}-0.333 \\
(1.430)\end{array}$ \\
\hline Backward_services & $\begin{array}{c}-7.576 * * * \\
(2.158)\end{array}$ & $\begin{array}{l}1.286 * \\
(0.674)\end{array}$ & $\begin{array}{c}-20.662 * * * \\
(6.324)\end{array}$ & $\begin{array}{l}5.331 * \\
(2.801)\end{array}$ & $\begin{array}{c}-9.719 * * \\
(4.698)\end{array}$ \\
\hline Forward_services & $\begin{array}{c}4.417 * * * \\
(1.492)\end{array}$ & $\begin{array}{c}3.110 * * * \\
(0.710)\end{array}$ & $\begin{array}{l}6.913 * \\
(4.147)\end{array}$ & $\begin{array}{c}6.150 * * * \\
(1.752)\end{array}$ & $\begin{array}{c}13.599 * * * \\
(5.205)\end{array}$ \\
\hline In Human capital & $\begin{array}{c}0.482 * * * \\
(0.014)\end{array}$ & $\begin{array}{c}0.488^{* * * *} \\
(0.016)\end{array}$ & $\begin{array}{c}0.295 * * * \\
(0.061)\end{array}$ & $\begin{array}{c}0.332 * * * \\
(0.014)\end{array}$ & $\begin{array}{c}0.526 * * * \\
(0.045)\end{array}$ \\
\hline ln Intangibles & $\begin{array}{c}0.045^{* * * *} \\
(0.003)\end{array}$ & $\begin{array}{c}0.077 * * * \\
(0.006)\end{array}$ & $\begin{array}{l}0.008 * \\
(0.004)\end{array}$ & $\begin{array}{c}0.060 * * * \\
(0.005)\end{array}$ & $\begin{array}{c}0.029 * * * \\
(0.006)\end{array}$ \\
\hline Age & $\begin{array}{c}-0.009 * * * \\
(0.002)\end{array}$ & $\begin{array}{c}-0.015 * * * \\
(0.002)\end{array}$ & $\begin{array}{l}-0.005 \\
(0.004)\end{array}$ & $\begin{array}{c}-0.009 * * * \\
(0.003)\end{array}$ & $\begin{array}{c}-0.010 * * * \\
(0.002)\end{array}$ \\
\hline Age squared & $\begin{array}{l}0.000 * \\
(0.000)\end{array}$ & $\begin{array}{c}0.000 * * * \\
(0.000)\end{array}$ & $\begin{array}{l}-0.000 \\
(0.000)\end{array}$ & $\begin{array}{l}0.000 * \\
(0.000)\end{array}$ & $\begin{array}{c}0.000 \\
(0.000)\end{array}$ \\
\hline ln Size & $\begin{array}{c}0.213 * * * \\
(0.018)\end{array}$ & $\begin{array}{c}0.270 * * * \\
(0.024)\end{array}$ & $\begin{array}{l}0.080 * \\
(0.049)\end{array}$ & $\begin{array}{c}0.146 * * * \\
(0.032)\end{array}$ & $\begin{array}{l}-0.026 \\
(0.059)\end{array}$ \\
\hline ln Size squared & $\begin{array}{c}-0.004 * * * \\
(0.001)\end{array}$ & $\begin{array}{c}-0.007 * * * \\
(0.002)\end{array}$ & $\begin{array}{c}0.000 \\
(0.003)\end{array}$ & $\begin{array}{l}-0.003 \\
(0.002)\end{array}$ & $\begin{array}{c}0.011 * * \\
(0.005)\end{array}$ \\
\hline HHI & $\begin{array}{c}-0.232 * * * \\
(0.062)\end{array}$ & $\begin{array}{l}0.241 * \\
(0.136)\end{array}$ & $\begin{array}{l}-0.142 \\
(0.116)\end{array}$ & $\begin{array}{l}-0.159 \\
(0.106)\end{array}$ & $\begin{array}{l}-0.189 \\
(0.132)\end{array}$ \\
\hline ln Demand & $\begin{array}{l}-0.033 \\
(0.024) \\
\end{array}$ & $\begin{array}{l}-0.046 \\
(0.033)\end{array}$ & $\begin{array}{r}0.066 \\
(0.047) \\
\end{array}$ & $\begin{array}{l}-0.020 \\
(0.016)\end{array}$ & $\begin{array}{c}0.029 \\
(0.100)\end{array}$ \\
\hline \multicolumn{6}{|l|}{ Model diagnostics } \\
\hline No. of observations & 29,263 & 11,451 & 2,499 & 8,140 & 3,584 \\
\hline No. of groups & 9,712 & 2,870 & 1,278 & 3,074 & 1,136 \\
\hline No. of Instruments & 55 & 86 & 107 & 60 & 81 \\
\hline Year effects & yes & yes & yes & yes & yes \\
\hline Region effects & yes & yes & yes & yes & yes \\
\hline Industry effects & yes & yes & yes & yes & yes \\
\hline $\operatorname{AR}(1) p$-value & 0 & 0 & 0 & 0 & 0 \\
\hline $\operatorname{AR}(2) p$-value & 0.562 & 0.788 & 0.569 & 0.722 & 0.343 \\
\hline Hansen J Test p-value & 0.106 & 0.107 & 0.682 & 0.755 & 0.353 \\
\hline $\begin{array}{l}\text { Hansen C Test p-value } \\
\text { (lagged dependent) }\end{array}$ & 0.162 & 0.125 & 0.894 & 0.865 & 0.750 \\
\hline $\begin{array}{l}\text { Hansen C Test p-value } \\
\text { (equation in levels) }\end{array}$ & 0.073 & 0.213 & 0.460 & 0.902 & 0.469 \\
\hline
\end{tabular}

Notes: Robust standard errors in parenthesis. Windmeijer's finite-sample correction is applied to two-step estimations. $* * *$ significant at $1 \%$, ** significant at $5 \%$, and * significant at $10 \%$. 
As far as backward linkages are concerned (H2), the results suggest that, in all countries except Estonia, presence of foreign firms in manufacturing sectors benefits upstream domestic suppliers. The positive effects on local firms' productivity range from 1.7 per cent in the Czech Republic to 2.8 per cent in Hungary. These results are in line with most empirical studies (Havránek and Iršová, 2011) suggesting that countries such as the Czech Republic, Hungary and Slovakia which attracted large amount of FDI in tradable sectors are able to benefit from entering MNCs' production network.

Turning to backward linkages from services, positive effects on local manufacturing firms' productivity are evident only in Estonia and Slovakia, and are larger in magnitude in comparison to backward linkages from manufacturing. On the other hand, negative backward linkages from services are evident in manufacturing firms in the Czech Republic, Hungary and Slovenia and offset any positive effects arising from FDI in manufacturing sector. These findings are in line with those obtained by Mariotti et al. (2013) who found that four service sectors exhibit negative effects on upstream manufacturing firms unless the entry of MNCs is able to increase demand for intermediate manufacturing inputs. Ayyagari and Kosova (2010) found similar results when investigating the effects of backward linkages from services on the entry of domestic firms. They explain this by the fact that manufacturing firms usually supply only limited amount of intermediate inputs to services in form of communication and information technology and office automation equipment. Since in these industries barriers to entry may be high and foreign presence is significant, services firms may be more inclined to source from their foreign suppliers.

The findings with respect to forward spillovers (H3) suggest that inputs supplied by MNCs in manufacturing sector have detrimental effects on TFP in all countries, but are only statistically significant in the Czech Republic, Estonia and Hungary. A one percentage point increase in foreign presence in upstream manufacturing sector leads to decline in TFP levels between 1.3 (Estonia) and 3.1 (Hungary) percent. The results suggest that domestic firms may not have the capabilities to benefit from high quality inputs because of the difficulties in the integration of these into the production process. In addition, the motives of foreign manufacturing firms in CEECs are mostly efficiency-seeking, aiming to exploit low wages in production or to gain access to intermediate inputs at favourable costs. Therefore, their embeddedness into local market and the need to gain insight into the needs and requirements of potential customers in manufacturing sector is low. As evident from Figure A1 in Appendix A, an alternative explanation is that foreign firms may have gained a dominant market position in upstream sectors such as electrical and optical equipment industry, transportation and other machineries, enabling them to gain market power and better bargaining position in the sector resulting in higher priced inputs (Newman et al., 2015). 
In the case of forward spillovers from the service sector $(\mathrm{H} 4)$, the results indicate strong positive and significant effect of foreign owned services on downstream manufacturing productivity, thus confirming previous findings on the beneficial effects of FDI in services (Arnold et al., 2011; Fernandes and Paunov, 2012; Mariotti et al., 2013). The short run effects range from 3.1 per cent in Estonia to 13.6 per cent in Slovenia. Such large semi-elasticities may reflect the FDI penetration ratios in the service sector due to recent liberalisation where effects are expected to be larger for an increase in foreign presence from small levels than in sectors where levels of FDI are already saturated (Gersl et al., 2008). The evidence seems to indicate that productivity spillovers are more easily captured by manufacturing customers that buy inputs from services MNCs than through backward services linkages or forward manufacturing linkages.

For variables measuring absorptive capacity, the empirical findings suggest a positive and significant relationship between the human capital measure and TFP across all countries. One percent increase in average wage leads to 0.3 per cent increase in productivity in Hungary and up to 0.5 per cent in Slovenia. Similarly, the intensive use of intangible assets has a positive and significant effect in all countries; this is in line with other empirical studies examining the impact of intangibles on productivity (Marrocu et al., 2012; Hall et al., 2013; Battistini et al., 2015). Firm age suggests a nonlinear relationship in almost all countries except in Hungary where it is not significant and in Slovenia where there seems to be a negative linear effect of age. Firm's size has a positive and significant effect in all countries, except Slovenia. Inverse-U shape effects can be found in the Czech Republic and Estonia suggesting that after firms achieve a certain size their effects on productivity starts to diminish. Finally, the effects of demand in downstream sectors are statistically insignificant.

\subsection{EXPLORING THE MECHANISM OF HORIZONTAL SPILLOVERS}

The absence of positive horizontal spillovers across countries indicates that it is important to differentiate between different mechanisms through which they occur, something we investigate next. To shed more light on three possible channels of horizontal spillovers, we augment our baseline model by including interaction terms between foreign presence in each 2-digit manufacturing industry and the level of human capital measured by the average wage in the industry. This interaction term serves as a proxy for labour mobility effects as the influence of foreign firms would be co-determined by the level of human capital of the local firms (Ben Hamida, 2013). 
Demonstration and competition effects are measured as before. For brevity of space, we report only the results for different horizontal channels in Table $3 .^{13}$

Table 3. Horizontal spillovers from FDI

\begin{tabular}{cccccc}
\hline & Czech Republic & Estonia & Hungary & Slovakia & Slovenia \\
\hline Demonstration & $-3.231 * * *$ & $-1.515^{* * *}$ & $-2.623 * *$ & $-2.324 * * *$ & 0.821 \\
& 0.804 & 0.298 & 1.245 & 0.629 & 2.51 \\
Worker mobility & $1.157 * * *$ & $0.539 * * *$ & $0.730 *$ & $0.984 * * *$ & -0.256 \\
& 0.308 & 0.143 & 0.443 & 0.265 & 0.867 \\
Competition & $-0.219 * * *$ & $0.315^{* * *}$ & $-0.209 *$ & $-0.212 *$ & -0.201 \\
& 0.071 & 0.118 & 0.108 & 0.124 & 0.126 \\
\hline
\end{tabular}

Notes: Robust standard errors in parenthesis. Windmeijer's finite-sample correction is applied to two-step estimations. $* * *$ significant at $1 \%$, ** significant at $5 \%$, and $*$ significant at $10 \%$.

Results indicate that our proxy for labour mobility and increased competition are associated with higher levels of productivity of domestic firms, while demonstration effects remain negative and significant. Our findings suggest that although domestic firms need to offer high wage premium to attract skilled and experienced employees from MNCs it is less costly to provide training internally. In line with theoretical model of Fosfuri et al. (2001) it seems that the productivity premium is higher than the wage premium.

\subsection{MODERATING ROLE OF ABSORPTIVE CAPACITY}

The occurrence of FDI spillovers is not an automatic process and does not benefit all firms equally. In line with the literature emphasising that domestic firm heterogeneity play an important role in explaining FDI spillovers (Damijan et al., 2013; Jude, 2016) we exploit the concept of absorptive capacity in more detail. As noted by Cohen and Levinthal (1990) and George and Zahra (2002), absorptive capacity helps firms to identify, assimilate, transform and apply knowledge from the external environment. Therefore, benefits from FDI spillovers are more likely to occur in firms that are better able to absorb the technology that comes with MNCs. In this section, we test whether the intensity of a firm's intangible assets has a moderating effect on FDI spillovers. The use of intangible assets has potentially several advantages over other measures of absorptive capacity. First, intangible capital is a broader measure of absorptive capacity as it includes both innovation inputs and outputs developed in house or in arms-length transactions which leads to improvements in production process. Second, as suggested by Teece (2011) intangible assets consist of mostly non-

\footnotetext{
${ }^{13}$ In an augmented model we have also interacted vertical spillovers with the levels of human capital, however the results are fairly similar to those obtained when exploring the role of absorptive capacity (reported below).
} 
codified knowledge and thus contribute to firm specific assets which in turn sustain firm competitiveness. ${ }^{14}$ Third, intangible capital has been found to be a strong determinant of firm productivity in many studies (Syverson, 2011). Unlike other studies which use technological gap vis-a-vis foreign firms as proxy for absorptive capacity our measure considers innovation efforts undertaken to be able to use foreign knowledge productively.

Based on the above discussion, we test an additional hypothesis:

H6: The magnitude of horizontal spillovers and vertical linkages is greater for domestic firms with higher intangible assets ratio.

The model presented by equation (4) is now augmented by adding interaction terms between each FDI spillover measure and the logarithm of intangible to tangible fixed assets ratio. Since the interaction terms include two continuous variables we present the marginal effects of FDI spillovers on TFP conditional on the values of intangible asset ratio at the $10^{\text {th }}, 25^{\text {th }}, 50^{\text {th }}, 75^{\text {th }}$, and $90^{\text {th }}$ percentiles. We find that the higher intensity of intangibles attenuates the negative horizontal spillover effects in Estonia and Slovakia while in Slovenia a statistically insignificant spillover effect at lower levels of intangible asset ratio becomes positive and significant at higher values (Figure 1). Results for the Czech Republic are contrary to expectations as the negative horizontal spillover effects get stronger with increases in intangible assets.

\footnotetext{
${ }^{14}$ For example, knowledge capital of the firm incorporated in intangible assets include R\&D expenditure, software, patents, licences, designs, trademarks, organizational processes and firm specific skills that provide competitive advantages (Ragoussis, 2014).
} 
Figure 1. Average marginal effects of horizontal spillovers across intangible assets ratio percentiles
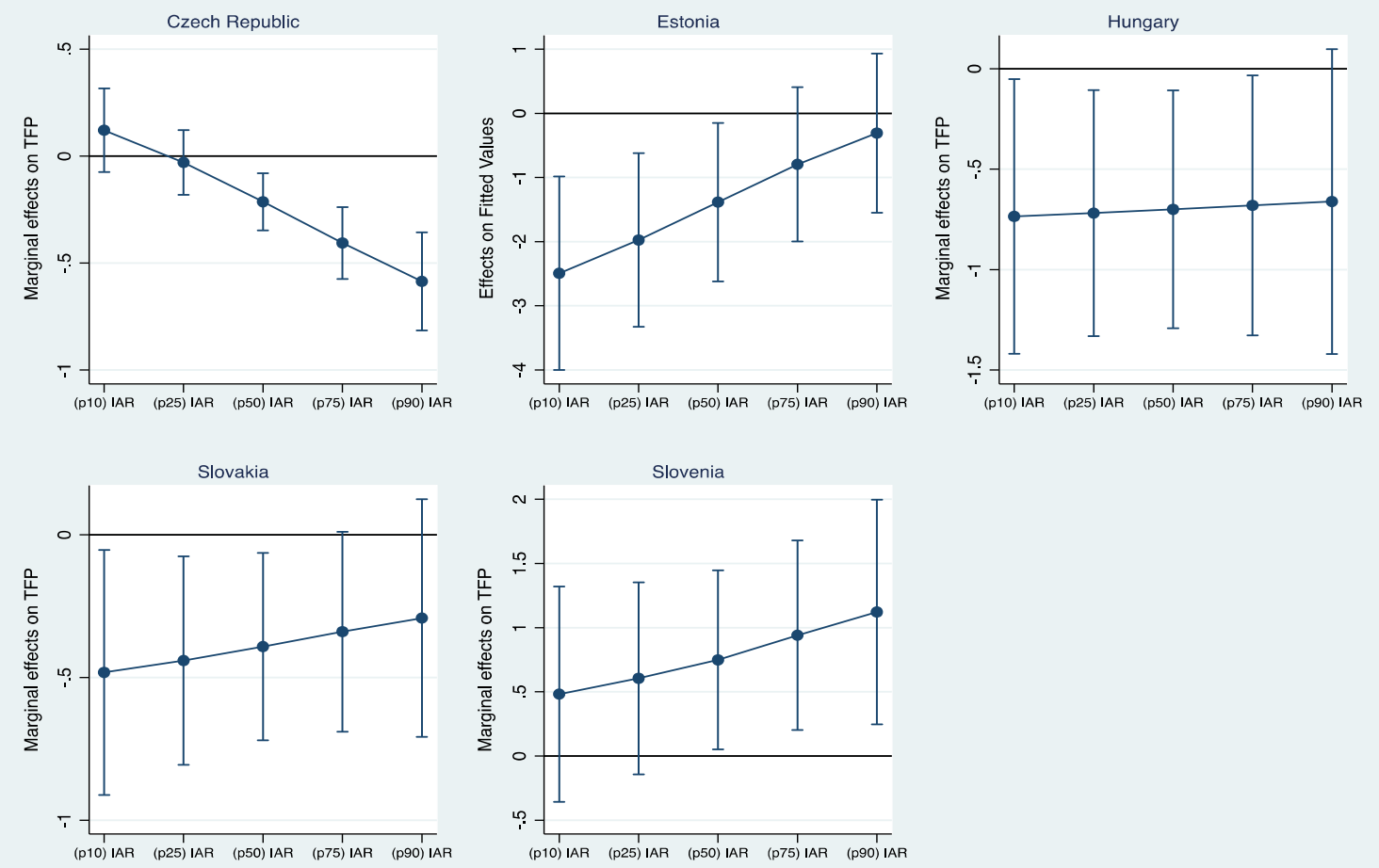

Turning to vertical linkages arising from manufacturing sectors, presented in Figure 2, findings suggest that domestic suppliers with higher absorptive capacity benefit from backward linkages only in the Czech Republic. In line with other studies, this result confirms the role of firm's absorptive capacity as an enabling factor for FDI spillovers (Crespo and Fontoura, 2007; Blalock and Gertler, 2008; Damijan et al., 2013). However, in other countries increases in absorptive capacity do not appear to lead to changes in the marginal effects on TFP. In case of forward linkages, the point estimates for the Czech Republic, Estonia, Slovakia suggest a declining impact with higher levels of intangible asset ratio, though the difference across different percentiles is not statistically significant, except in Estonia. 
Figure 2. Average marginal effects of manufacturing vertical linkages across intangible assets ratio percentiles
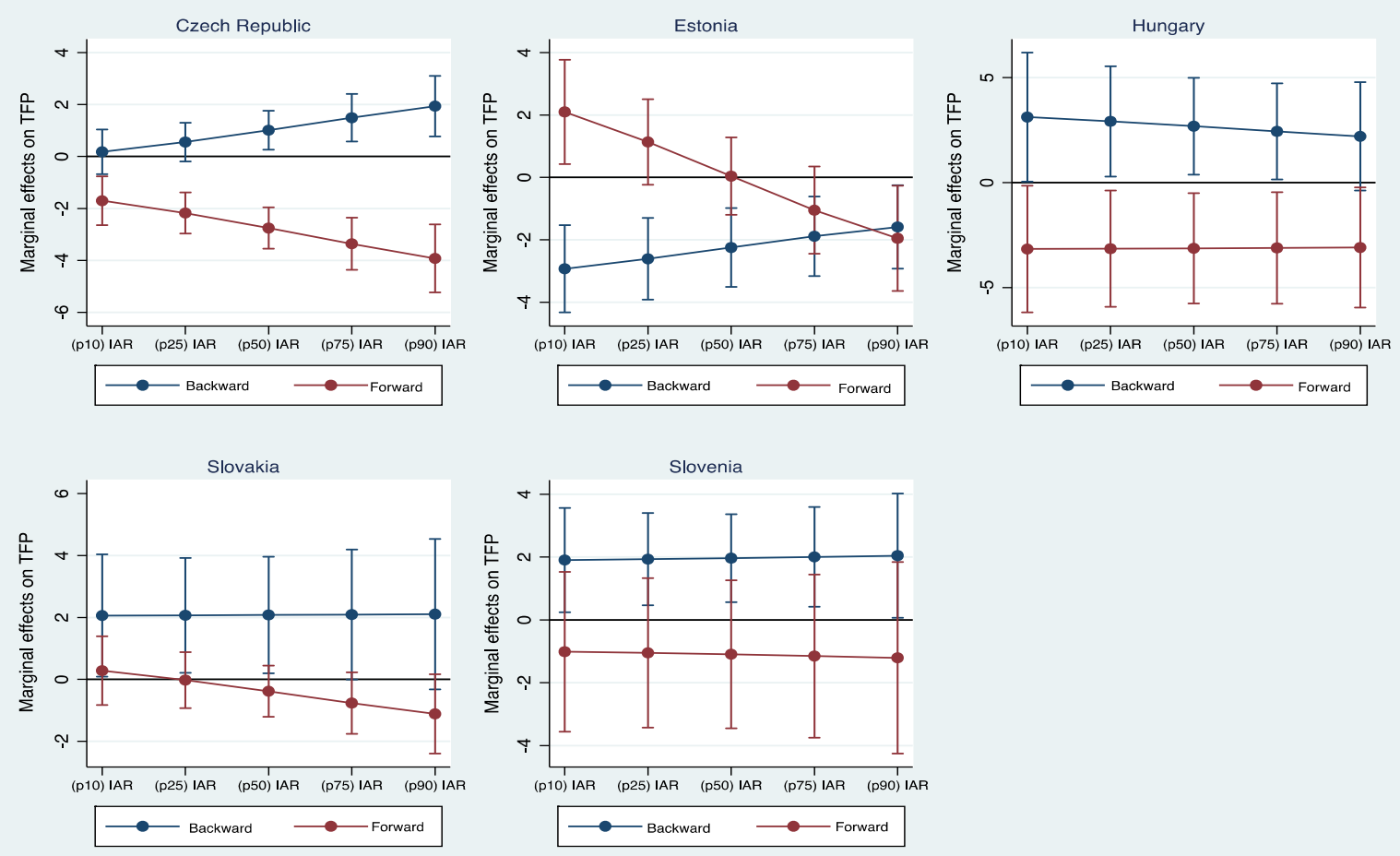

Turning to linkages arising from the service sector, presented in Figure 3, the statistically insignificant effects of forward linkages becomes positive and significant for higher levels of intangible asset ratio in the Czech Republic while the moderating effects are insignificant in the rest of the countries. Finally, none of the countries examined appear to benefit from backward vertical linkages with increased levels of absorptive capacity. 
Figure 3. Average marginal effects of services vertical linkages across intangible assets ratio percentiles
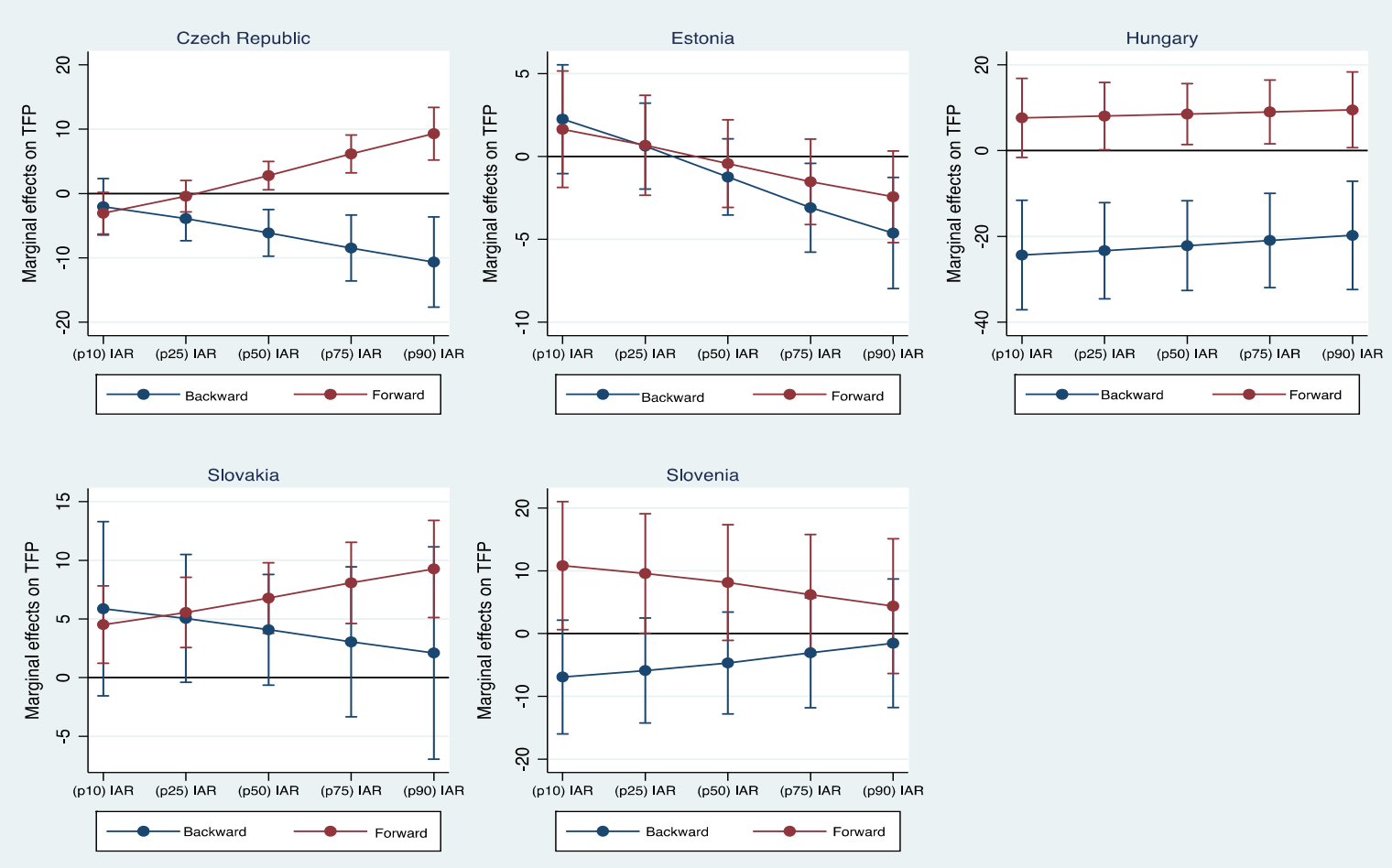

There may be a few potential reasons for these largely unexpected results for most countries. The proxy used for measuring absorptive capacity may not distinguish between different types of intangible capital; only externally acquired assets can be capitalized and therefore recognized as intangible asset while those assets generated internally is often expensed (Ragoussis, 2014). Even if intangible asset is bought on the market it requires specific dynamic capabilities to be accumulated and managed. Given rapid technological changes, the existence of organizational capabilities evident in routines and processes is required to refine and transform the knowledge (Nelson and Winter, 1982; Grant, 1996; Dosi et al., 2000; George and Zahra, 2002). Another critical resource in the process of intangible asset accumulation and exploitation is related to human capital (Abramovitz and David, 2000). Since the creation of specific competence in human capital requires hiring staff with higher education as well as formal and informal on-the-job training the costs may become too high causing firms to minimize investment in intangible asset (Cuervo-Cazurra and Un, 2009) and lead to heterogeneous patterns of investment in, and management of, intangible assets (Arrighetti et al., 2015). ${ }^{15}$

\footnotetext{
${ }^{15}$ Economic competencies (e.g. human capital and organizational structure) are regarded as the most important part of intangible asset which are most difficult to measure and therefore are not included in the balance sheet. Given that they are important for the assimilation and exploitation of external knowledge, a limited set of capabilities included in our measure may hamper the complementarities between different types intangible asset and result in insignificant or in some cases negative moderating effects.
} 


\subsection{THE IMPORTANCE OF KNOWLEDGE INTENSIVE SERVICES}

This section aims to shed more light on the role of knowledge intensity by separating forward linkages from services to those coming from less and more knowledge intensive industries. We employ standard Eurostat definition of knowledge intensive (KIS) and less knowledge intensive services (LKIS) as in Masso and Vahter (2012). ${ }^{16}$ The results of the augmented model where services forward linkages are now separated according to KIS and LKIS are presented in Table 3.

The results show that KIS drive the positive effects of services forward linkages reported in the baseline model in Table 3, thus supporting H5. The largest effects are experienced by domestic firms in Hungary, Slovenia and the Czech Republic where a one percentage point increase in foreign firms' presence in KIS results in an increase in TFP between 8.93 and 19.75 percent. The only country in which LKIS have any positive and significant effect is Slovenia. Since FDI is industry specific (Buckley et al., 2007; Wang et al., 2009) and technology characteristics as well as potential for knowledge absorption differ across industries (Spencer, 2008; Wang et al., 2012), we have further split manufacturing sector into high-tech and low-tech industries according to R\&D intensity as defined by the OECD (2007). The results suggest significant positive effects of forward KIS on manufacturing firms in high-tech industries across all countries, except in Slovenia. ${ }^{17}$ In addition, the beneficial effects of forward KIS on low-tech manufacturing firms are found in Hungary, Slovenia and Slovakia. In contrast, forward linkages from LKIS have mostly negative and significant effects on their downstream manufacturing customers in both types of industries in all countries except Slovenia. Overall, these results complement previous studies which found KIS to have a positive impact on downstream customers (Camacho and Rodriguez, 2007; Evangelista et al., 2013; Mariotti et al., 2013).

\footnotetext{
${ }^{16}$ Within the NACE 1.1 classification system the following industries are defined as knowledge intensive service sectors: water transport (NACE code 61), air transport (62), post and telecommunications (64), financial intermediation (65), insurance (66), activities auxiliary to financial intermediation (67), real estate activities (70), renting of machinery and equipment (71), computer and related activities (72), research and development (73) and other business activities (74). On the other hand, less knowledge intensive services sectors are: wholesale and retail trade (50-52), hotels and restaurants (55), land transport (60), and supporting and auxiliary transport activities (63).

${ }^{17}$ Estimation results are not reported here for brevity of space. Full estimation results could be obtained from the authors on request.
} 
Table 4. System-GMM results of FDI productivity spillovers, forward KIS vs. LKIS linkages

\begin{tabular}{|c|c|c|c|c|c|}
\hline VARIABLES & Czech Republic & Estonia & Hungary & Slovakia & Slovenia \\
\hline Lagged $\ln$ TFP & $\begin{array}{c}0.473 * * * \\
(0.042)\end{array}$ & $\begin{array}{c}0.285^{* * *} * \\
(0.027)\end{array}$ & $\begin{array}{c}0.621 * * * \\
(0.087)\end{array}$ & $\begin{array}{c}0.374 * * * \\
(0.042)\end{array}$ & $\begin{array}{c}0.436 * * * \\
(0.054)\end{array}$ \\
\hline Horizontal & $\begin{array}{c}-0.233 * * * \\
(0.072)\end{array}$ & $\begin{array}{c}-0.417 * * \\
(0.178)\end{array}$ & $\begin{array}{l}-0.603 * \\
(0.321)\end{array}$ & $\begin{array}{c}-0.533 * * \\
(0.231)\end{array}$ & $\begin{array}{c}0.136 \\
(0.315)\end{array}$ \\
\hline Backward_manufacturing & $\begin{array}{c}0.944 * * * \\
(0.294)\end{array}$ & $\begin{array}{c}-0.926^{* *} \\
(0.405)\end{array}$ & $\begin{array}{c}1.178 \\
(1.377)\end{array}$ & $\begin{array}{l}2.469 * \\
(1.357)\end{array}$ & $\begin{array}{l}1.458 * \\
(0.775)\end{array}$ \\
\hline Forward_manufacturing & $\begin{array}{l}-0.719 \\
(1.853)\end{array}$ & $\begin{array}{l}-0.739 \\
(0.553)\end{array}$ & $\begin{array}{l}-2.808 * \\
(1.470)\end{array}$ & $\begin{array}{c}-4.376 * * \\
(2.024)\end{array}$ & $\begin{array}{c}0.152 \\
(1.251)\end{array}$ \\
\hline Backward_services & $\begin{array}{c}-8.240 * * * \\
(1.657)\end{array}$ & $\begin{array}{l}1.230 * \\
(0.740)\end{array}$ & $\begin{array}{c}-16.014 * * * \\
(5.581)\end{array}$ & $\begin{array}{c}1.945 \\
(3.710)\end{array}$ & $\begin{array}{l}-8.713 * \\
(4.573)\end{array}$ \\
\hline ForwardKIS & $\begin{array}{c}8.932 * * * \\
(3.092)\end{array}$ & $\begin{array}{l}2.229 * \\
(1.283)\end{array}$ & $\begin{array}{c}19.748 * * \\
(8.586)\end{array}$ & $\begin{array}{l}3.432 * \\
(2.029)\end{array}$ & $\begin{array}{l}13.212 * \\
(7.732)\end{array}$ \\
\hline ForwardLKIS & $\begin{array}{l}-1.102 \\
(1.680)\end{array}$ & $\begin{array}{c}0.200 \\
(1.919)\end{array}$ & $\begin{array}{c}2.615 \\
(7.858)\end{array}$ & $\begin{array}{c}0.465 \\
(0.340)\end{array}$ & $\begin{array}{c}12.652 * * * \\
(4.806)\end{array}$ \\
\hline In Human capital & $\begin{array}{c}0.435 * * * \\
(0.024)\end{array}$ & $\begin{array}{c}0.481 * * * \\
(0.016)\end{array}$ & $\begin{array}{c}0.278 * * * \\
(0.049)\end{array}$ & $\begin{array}{c}0.335^{* * *} \\
(0.015)\end{array}$ & $\begin{array}{c}0.509 * * * \\
(0.043)\end{array}$ \\
\hline ln Intangibles & $\begin{array}{c}0.038 * * * \\
(0.004)\end{array}$ & $\begin{array}{c}0.073 * * * \\
(0.006)\end{array}$ & $\begin{array}{l}0.007 * \\
(0.004)\end{array}$ & $\begin{array}{c}0.060 * * * \\
(0.005)\end{array}$ & $\begin{array}{c}0.028 * * * \\
(0.005)\end{array}$ \\
\hline Age & $\begin{array}{c}-0.007 * * * \\
(0.002)\end{array}$ & $\begin{array}{c}-0.015 * * * \\
(0.002)\end{array}$ & $\begin{array}{l}-0.005 \\
(0.004)\end{array}$ & $\begin{array}{c}-0.009 * * * \\
(0.003)\end{array}$ & $\begin{array}{c}-0.011 * * * \\
(0.003)\end{array}$ \\
\hline Age squared & $\begin{array}{c}0.000 * * \\
(0.000)\end{array}$ & $\begin{array}{c}0.000 * * * \\
(0.000)\end{array}$ & $\begin{array}{l}-0.000 \\
(0.000)\end{array}$ & $\begin{array}{l}0.000 * \\
(0.000)\end{array}$ & $\begin{array}{c}0.000 \\
(0.000)\end{array}$ \\
\hline ln Size & $\begin{array}{c}0.161 * * * \\
(0.029)\end{array}$ & $\begin{array}{c}0.251 * * * \\
(0.030)\end{array}$ & $\begin{array}{c}0.064 \\
(0.049)\end{array}$ & $\begin{array}{c}0.151 * * * \\
(0.032)\end{array}$ & $\begin{array}{l}-0.001 \\
(0.056)\end{array}$ \\
\hline In Size squared & $\begin{array}{c}-0.003 * * * \\
(0.001)\end{array}$ & $\begin{array}{c}-0.006 * * \\
(0.003)\end{array}$ & $\begin{array}{c}0.001 \\
(0.003)\end{array}$ & $\begin{array}{l}-0.003 \\
(0.002)\end{array}$ & $\begin{array}{l}0.008 * \\
(0.004)\end{array}$ \\
\hline HHI & $\begin{array}{c}-0.295 * * * \\
(0.063)\end{array}$ & $\begin{array}{c}0.306 \\
(0.244)\end{array}$ & $\begin{array}{l}-0.208 * * \\
(0.099)\end{array}$ & $\begin{array}{l}-0.114 \\
(0.109)\end{array}$ & $\begin{array}{l}-0.215^{*} \\
(0.124)\end{array}$ \\
\hline ln Demand & $\begin{array}{l}-0.000 \\
(0.019)\end{array}$ & $\begin{array}{l}-0.022 \\
(0.038)\end{array}$ & $\begin{array}{l}0.103 * \\
(0.058)\end{array}$ & $\begin{array}{l}-0.009 \\
(0.018)\end{array}$ & $\begin{array}{l}-0.003 \\
(0.062)\end{array}$ \\
\hline \multicolumn{6}{|l|}{ Model diagnostics } \\
\hline No. of observations & 29,263 & 11,451 & 2,499 & 8,140 & 3,584 \\
\hline No. of groups & 9,712 & 2,870 & 1,278 & 3,074 & 1,136 \\
\hline No. of instruments & 60 & 68 & 95 & 66 & 90 \\
\hline Year effects & yes & yes & yes & yes & yes \\
\hline Region effects & yes & yes & yes & yes & yes \\
\hline Industry effects & yes & yes & yes & yes & yes \\
\hline $\operatorname{AR}(1) p$-value & 0 & 0 & 0 & 0 & 0 \\
\hline $\operatorname{AR}(2) p$-value & 0.578 & 0.589 & 0.578 & 0.781 & 0.330 \\
\hline Hansen J Test p-value & 0.262 & 0.261 & 0.796 & 0.677 & 0.449 \\
\hline $\begin{array}{l}\text { Hansen C Test p-value } \\
\text { (lagged dependent) }\end{array}$ & 0.480 & 0.880 & 0.877 & 0.905 & 0.262 \\
\hline $\begin{array}{l}\text { Hansen } C \text { tests } p \text {-value } \\
\text { (levels equation) }\end{array}$ & 0.218 & 0.318 & 0.900 & 0.880 & 0.266 \\
\hline
\end{tabular}

Notes: Robust standard errors in parenthesis. Windmeijer's finite-sample correction is applied to two-step estimations. $* * *$ significant at $1 \%$, ** significant at $5 \%$, and $*$ significant at $10 \%$. 


\section{CONCLUSION AND POLICY RECOMMENDATIONS}

This article explores the effects of FDI spillovers on productivity of domestic firms in the manufacturing sectors of five CEE countries (the Czech Republic, Estonia, Hungary, Slovakia and Slovenia) between 2002 and 2010. It contributes to the existing scarce literature on productivity spillovers arising from FDI in the service sector (Arnold et al., 2011; Fernandes and Paunov, 2012; Mariotti et al., 2013) by examining whether the increased presence of MNCs encouraged by the recent liberalization of services leads to productivity improvements of domestic manufacturing firms. In addition, it sheds more light on different mechanisms through which foreign firms influence their direct competitors. This is an advancement compared with the existing literature which pools the different horizontal spillovers channels into a single aggregate coefficient. To the best of our knowledge, this is the first empirical study using firm level data and annual input-output tables for CEE countries that also disentangles vertical spillovers per industry source.

The results suggest that local manufacturing firms benefit from the backward spillovers in manufacturing and forward spillover effects of FDI in services. This confirms previous empirical findings that MNCs have a strong incentive to share knowledge with their suppliers (Javorcik, 2004; Damijan et al., 2013; Jude, 2016). They are also consistent with the view that the liberalization of services and the subsequent increased entry of MNCs is associated with improved availability, range and quality of services resulting in improved performance of downstream manufacturing firms (Arnold et al, 2011; Mariotti et al., 2013). Additionally, we found that the positive spillovers of FDI in services to manufacturing customers is driven by the presence of foreign firms in KIS. Despite positive forward spillovers from services, we confirm the previous literature highlighting negative manufacturing forward linkages that outweigh positive effects on their suppliers in the Czech Republic, Estonia and Hungary. It thus seems that domestic firms in downstream sectors are less fitted to benefit from technology spillovers then their domestic counterpart in upstream industries. In addition, local manufacturing supplier firms do not benefit from increased presence of MNCs in services except in Slovakia and Hungary.

We further contribute to the literature by investigating the different mechanisms of horizontal spillovers and explore the moderating effects of absorptive capacity. We find that knowledge diffusion within sectors mostly occur through worker mobility, while demonstration and competition effects exhibit negative effects on domestic firms' productivity. Additionally, gains from the presence of MNCs do not accrue equally to all firms. Those firms in the Czech Republic that have higher intensity of intangible asset ratio as a proxy for absorptive capacity are more likely 
to benefit from manufacturing backward and services forward linkages while the negative effects of intra industry spillovers are attenuated in Estonia and Slovakia.

\subsection{POLICY RECOMMENDATIONS}

Given the positive impact of foreign entry in services, particularly the KIS, on the performance of downstream manufacturing firms, policy makers should make every effort to encourage the greater presence of MNCs in services. However, more attention should be paid to the type and skill content of FDI in services. So far, CEE suppliers have been successful in integrating production network of MNCs in manufacturing sector, but the bulk of recent FDI in services characterised by vertical cost driven investment has still not been able to create backward spillovers.

Governments should provide information about any industry specific requirements needed by MNCs to facilitate the creation of vertical linkages and entry of indigenous firms into global value chains. Policy makers should encourage the entry of knowledge intensive services firms, thus contributing to the development of knowledge-based economy. Increased interaction within these group of services would facilitate the exchange of tacit and codified knowledge and increase the local embeddedness of foreign firms. Since CEE already possess certain comparative advantages evident in low cost high skilled labour, cultural similarity, favourable geographical location and relatively developed infrastructure, host countries at national and regional level should develop their innovation capabilities and invest in intangible asset building upon their existing education and skills. By fostering linkages with MNCs and matching domestic capacities with dynamics of global value chains, especially in those characterised by modular or relational governance favourable to an open-ended upgrading through knowledge sharing, domestic firms with sufficient absorptive capability are more likely to benefit from technological spillovers and functionally upgrade to activities with higher value added. Therefore, investment incentives already in place should promote interaction with foreign firms, and be accompanied by innovation and knowledge promotion policies.

Regarding the managerial implications, our findings suggest that domestic suppliers to MNCs in manufacturing sector and manufacturing customers of MNCs in services should extend their linkages as they provide wider benefits to the economy in terms of indirect productivity spillovers. By contrast, domestic customers of manufacturing MNCs and suppliers to services MNCs should aim to establish closer relationships with MNCs. One possibility is to ensure that local standards, certification and accreditation meet international standards and best practice which would 
potentially result in more extensive backward linkages with services customers and knowledge diffusion. Given the somewhat limited role of intangible asset to moderate the capacity to absorb FDI spillovers, more effort should be put in developing capacities of domestic firms by reducing technical and managerial skills gap with foreign investors. One approach would be for managers to actively engage in cooperation with local universities and research centres and to invest in innovation activities. Given the increased internationalization of R\&D and knowledge services managers of domestic firms should seek cooperation with foreign firms and encourage worker mobility by offering higher wages. In addition, given that manufacturing customers in high-tech sectors benefit more from services inputs, especially those coming from knowledge intensive services, managers of local manufacturing firms should ensure the assimilation and exploitation of the existing knowledge to increase their technological capabilities that would result in new processes, products and services and enable them to move up the value chain.

\subsection{LIMITATIONS AND DIRECTIONS FOR FUTURE RESEARCH}

As with previous studies, our paper is not without limitations. First, although we tried to disentangle different mechanisms of horizontal spillovers, our proxies for worker mobility and competition are not without drawbacks. Standard measure of horizontal spillovers based on foreign firms output in total industry output is only capturing net effects of demonstration and competition effects without disentangling pecuniary from technological spillovers. Future research should try to disentangle different mechanisms through which foreign firms affect their direct domestic competitors by using better data and methodology. With this aim, collecting data on worker mobility from MNCs to domestic firms would be a first step. Since competition effects are mostly pecuniary in nature, investigating the survival of domestic firms and their reaction upon MNC entry is a promising research avenue as it may shed more light on the effects of pecuniary versus technological spillovers.

Second, due to reliance on secondary databases, the availability of data limits the empirical boundaries of the research. For example, our measure of vertical linkages is based on industry level data, and thus assumes that sourcing behaviour of foreign firms is homogenous within industries. In addition, we are not able to differentiate between the extent and intensity of linkages and consequently between FDI spillovers arising through direct linkages and externalities accruing to all firms in downstream and upstream industries. To better advance the understanding of these issues, future research should generate and analyse firm level survey data. 
Recent IB studies have started looking at technological development, strategies and internal structure of MNCs and their effects on spillovers (Ghauri and Yamin, 2009). Given the importance of foreign firms' heterogeneity in terms of nationality, mode of entry, extent of ownership, intra firm strategies such as autonomy and technological capabilities and the nature and level of embeddedness of subsidiaries in local economy (Giroud, 2012), one should explore these issues in more depth. Furthermore, the heterogeneity of domestic firms in terms of international orientation, the level of internationalization and technological capabilities, and other factors influencing the scope and magnitude of spillovers should be considered. Unfortunately, the lack of detailed data regarding such characteristics hinders current empirical investigation. Finally, following Mariotti et al. (2015), further research could explore the role of spatial proximity of domestic and foreign firms. This would provide a promising step in advancing and understanding of the mechanism underlying productivity spillovers to domestic firms. 


\section{REFERENCES}

Abramovitz, M. and David, P.A. (2000). American Macroeconomic Growth in the Era of Knowledge-Based Progress: The Long-Run Perspective. In: Engermana, S.L., Gallman, R.E. (Eds). The Cambridge Economic History of the United States. Cambridge: Cambridge University Press.

Ackerberg, D.A., Caves, K. and Frazer, G. (2006). Structural identification of production functions. Unpublished manuscript.

Aitken, B. J. and Harrison, A. E. (1999). Do Domestic Firms Benefit from Direct Foreign Investment? Evidence from Venezuela. American Economic Review. 89(3). p. 605-618.

Alcacer, J. and Oxley, J. (2014). Learning by supplying. Strategic Management Journal. 35(2): 204-223.

Alfaro, L. and Rodriguez-Clare, A. (2004). Multinationals and Linkages: An Empirical Investigation. Economia. 4(2): 113-169.

Antonelli, C. (1999). The Microdynamics of Technological Change. London: Routledge.

Antras, P. and Yeaple, S.R. (2013). Multinational Firms and the Structure of International Trade. In G. Gopinath, E. Helpman and K. Rogoff (eds.). Handbook of International Economics. New York: Elsevier.

Arellano, M. and Bond, S. (1991). Some tests of specification for panel data: Monte Carlo evidence and an application to employment equations. Review of Economic Studies. (58): 277297.

Arellano, M., and Bover, O. (1995). Another look at the instrumental variable estimation of error-components models. Journal of Econometrics. (68): 29-51.

Arnold, J. M., B. S. Javorcik, and A. Mattoo (2011). Does services liberalization benefit manufacturing firms?: Evidence from the Czech Republic. Journal of International Economics. 85(1): 136-146.

Arrighetti, A., Landini, F. and Lasagni, A. (2015). Intangible Asset Dynamics and Firm Behaviour. Industry and Innovation. 22(5): 402-422.

Arrow, K. J. (1962). The Economic Implications of Learning by Doing. Review of Economic Studies. 29(3): 155-173.

Ayyagari, M and Kosova, R. (2010). Does FDI Facilitate Domestic Entry? Evidence from the Czech Republic. Review of International Economics. 18(1): 14-29.

Baldwin, R. and Lopez-Gonzalez, J. (2013). Supply-Chain Trade: A Portrait of Global Patterns and Several Testable Hypotheses. NBER Working Papers No. 18957.

Barbosa, N. and Eiriz, V. (2009). Linking corporate productivity to foreign direct investment: An empirical assessment. International Business Review. 18(1): 1-13. 
Barone, G. and Cingano, F. (2011). Service regulation and growth: evidence from OECD countries. The Economic Journal. 121(555): 931-957.

Barrios, S. H., Görg, H. and Strobl, E. (2011). Spillovers through Backward Linkages from Multinationals: Measurement Matters! European Economic Review. 55(6): 862-875.

Bartelsman, E., J. Haltiwanger, and S. Scarpetta. (2009). Measuring and Analyzing CrossCountry Differences in Firm Dynamics. In: T. Dunne, J. Bradford Jensen and M. Roberts (eds). Producer Dynamics: New Evidence from Micro Data. Cambridge MA: National Bureau of Economic Research.

Battistini, M., Belloc, F. and Del Gatto, M. (2015). Unbundling technology adoption and TFP at the firm level: do intangibles matter? Journal of Economics and Management Strategy. 24(2): 390-414.

Ben Hamida, L. (2013). Are there regional spillovers from FDI in the Swiss manufacturing industry? International Business Review. 22(4): 754-769.

Ben Hamida, L. and Gugler, P. (2009). Are there demonstration-related spillovers from FDI? Evidence from Switzerland. International Business Review. 18(5): 494-508.

Blalock, G. and Gertler, P. J. (2008). Welfare gains from Foreign Direct Investment through technology transfer to local suppliers. Journal of International Economics. 74(2): 402-421.

Blalock, G. and Simon, D.H. (2009). Do all firms benefit equally from downstream FDI? The moderating effect of local suppliers' capabilities on productivity gains. Journal of International Business Studies. 40(7): 1095-1112.

Blomström M. and Kokko A. (2001). Foreign direct investment and spillovers of technology. International Journal of Technology Management. 22(5/6): 435-454.

Blomström, M. and Kokko, A. (1998). Multinational Corporations and Spillovers. Journal of Economic Surveys. 12(3): 247-277.

Blundell, R., and Bond, S. (1998). Initial conditions and moment restrictions in dynamic panel data models. Journal of Econometrics. 87(1): 115-143.

Bourlès, R., Cette, G., Lopez, J., Mairesse, J. and Nicoletti, G. (2013). Do product market regulations in upstream sectors curb productivity growth? Panel data evidence for OECD Countries. Review of Economics and Statistics. 95(5): 1750-1768.

Buckley, P. J., Wang, C., and Clegg, J. (2007). The impact of foreign ownership, local ownership and industry characteristics on spillover benefits from foreign direct investment in China. International Business Review. 16(2): 142-158.

Camacho, J.A. and Rodriguez, M. (2007). How important are knowledge-intensive services for their client industries? An assessment of their impact on productivity and innovation. In: Gallouj, F. and Djellal, F. (Eds.). The Handbook of Innovation and Services. Cheltenham: Elgar. p. 424-447. 
Capik, P. and Drahokoupil, J. (2011). Foreign Direct Investments in Business Services: Transforming the Visegrád Four Region into a Knowledge-based Economy? European Planning Studies, 19(9): 1611-1631.

Casi L. and Resmini L. (2014) Spatial complexity and interactions in the FDI attractiveness of regions. Papers in Regional Science. 93 (Supplement S1): 51-78.

Caves, R. E. (1974). Multinational Firms, Competition and Productivity in Host Country Market. Economica. 41(162): 176-193.

Cohen, W. and Levinthal, D. (1990). Absorptive capacity: a new perspective on learning and innovation. Administrative Science Quarterly. 35(1):128-152.

CompNet Task Force (2014). Micro-Based Evidence of EU Competitiveness: The Compnet Database. ECB Working Paper Series 1634.

Consoli, D. and Elche-Hortelano, D. (2010). Variety in the knowledge base of Knowledge Intensive Business Services. Research Policy. 39(10): 1303-1310.

Crespo, N., and Fontoura, M. P. (2007). Determinant Factors of FDI Spillovers - What Do We Really Know? World Development. 35(3): 410-425.

Cuervo-Cazurra, A. and Un, A. C. (2009). Why some firms never invest in formal R\&D. Strategic Management Journal. 31(7): 759-779.

Damijan, J.P., Rojec, M., Majcen, B. and Knell, M. (2013). Impact of firm heterogeneity on direct and spillover effects of FDI: Micro-evidence from ten transition countries. Journal of Comparative Economics. 41(3): 895-922.

den Hertog, P. (2000). Knowledge-intensive business services as co-producers of innovation. International Journal of Innovation Management. 4(4): 491-528.

Dicken, P. (2003). Global Shift: Reshaping the Global Economic Map in the 21st Century. London: Sage.

Djankov, S. and Hoekman, B. (2000). Foreign Investment and Productivity Growth in Czech Enterprises. The World Bank Economic Review. 14(1): 49-64.

Djankov, S. and Murrell, P. (2002). Enterprise restructuring in transition: A quantitative survey. Journal of Economic Literature. 40(3): 739-792.

Doloreux, D. and Shearmur, R. (2012). Collaboration, information and the geography of innovation in knowledge intensive business services. Journal of Economic Geography. 12: 79105.

Dosi, G., Nelson R. and Winter S.G. (2000). The Nature and Dynamic of Organizational Capabilities. Oxford: Oxford University Press

Dossani, R. and Kenney, M. (2007). The next wave of globalisation: Relocating service provision to India. World Development. 35(5): 772-791. 
Driffield, N. and Jindra, B. (2012). Challenging the production function approach to assess the developmental effects of FDI. The European Journal of Development Research. 24(1): 32-37.

Dunning, J. H. and S. M. Lundan (2008). Multinational Enterprises and the Global Economy. Cheltenham: Edward Elgar Publishing.

Eapen, A. (2013). FDI spillover effects in incomplete datasets. Journal of International Business Studies. 44: 719-744.

Eschenbach, F. and B. Hoekman (2006). Services policy reform and economic growth in transition economies. Review of World Economics. 142(4):746-764.

Evangelista, R., Lucchese, M. and Meliciani, V. (2013). Business services, innovation and sectoral growth. Structural Change and Economic Dynamics. 25: 119-132.

Fernandes, A. M. and C. Paunov (2012). Foreign direct investment in services and manufacturing productivity: Evidence for Chile. Journal of Development Economics. 97(2): 305-321.

Fillipov, S. and Kalotay, K. (2009). Foreign direct investment in times of global economic crisis: spotlight on New Europe. UNU-Merit Working papers No. 21.

Findlay, R. (1978). Relative Backwardness, Direct Foreign Investment, and the Transfer of Technology: A Simple Dynamic Model. The Quarterly Journal of Economics. 92(1): 1-16.

Fosfuri, A., Motta, M. and Ronde, T. (2001). Foreign Direct Investment and Spillovers through Workers' Mobility. Journal of International Economics. 53(1): 205-222.

Francois J. (1990). Producer services, scale and the division of labor. Oxford Economic Papers. 42(4): 715-729.

Francois J. and Wörz, J. (2008). Producer Services, Manufacturing Linkages and Trade. Journal of Competition, Industry and Trade. 8(3): 199-229.

Gabrisch, H. and J. Hölscher (2006): The Successes and Failures of Economic Transition. New York: Palgrave Macmillan.

Gal, P. N. (2013). Measuring Total Factor Productivity at the Firm Level using OECD-ORBIS. OECD Economics Department Working Papers, No. 1049.

Garcia, F., Jin, B. and Salomon, R. (2013). Does inward foreign direct investment improve the innovative performance of local firms? Research Policy. 42(1): 231-244.

George, G. and Zahra, S. (2002). Absorptive capacity: a review, reconceptualization, and extension. Academy of Management Review: 27(2): 185-203.

Gersl, A., Rubene, I. and Zumer, T. (2008). Foreign direct investment and productivity spillovers in Central and Eastern European countries. In: Kowalewski, O. and Marzenna, A. $\mathrm{W}$. (eds.). The role of foreign direct investment in the economy. Rainer Hampp Verlag: München und Mering, 93-126. 
Ghauri, P. and Yamin, M. (2009). Revisiting the impact of multinational enterprises on economic development. Journal of World Business. 44(2): 105-107.

Giroud, A. (2007). MNEs vertical linkages: The experience of Vietnam after Malaysia. International Business Review. 16(2): 159-176.

Giroud, A. (2012). Mind the gap: how linkages strengthen understanding of spillovers. The European Journal of Development Research. 24(1): 20-25.

Glass, A. and Saggi, K. (2002). Multinational Firms and Technology Transfer. Scandinavian Journal of Economics. 104(4): 495-514.

Görg, H. and Greenaway, D. (2004) Much Ado About Nothing? Do Domestic Firms Really Benefit from Foreign Direct Investment? World Bank Research Observer. 19(2): 171-197.

Görg, H. and Strobl, E. (2001): Multinational Companies and Productivity Spillovers: A Metaanalysis. The Economic Journal. 111(475): 723-739.

Grant, R. M. (1996). Towards a knowledge-based theory of the firm. Strategic Management Journal. 17: 109-122.

Griliches, Z. (1992): The Search for R\&D Spillovers. The Scandinavian Journal of Economics. 94: 29-47.

Guerrieri, P. and Meliciani, V. (2005). Technology and international competitiveness: the interdependence between manufacturing and producer services. Structural Change and Economic Dynamics. 16: 489-502.

Ha, Y. J. and Giroud, A. (2015). Competence creating subsidiaries and FDI technology spillovers. International Business Review. 24(4): 605-614.

Hale, G. and Long, C. (2011). Are There Productivity Spillovers From Foreign Direct Investment In China? Pacific Economic Review. 16(2): 135-153.

Hall, B.H., Lotti, F. and Mairesse, J. (2013). Evidence on the impact of R\&D and ICT investments on innovation and productivity in Italian firms. Economics of Innovation and New Technology. 22(3): 300-328.

Hallin, C. and Holmstrom-Lind, C. (2012). Revisiting the external impact of MNCs: An empirical study of the mechanisms behind knowledge spillovers from MNC subsidiaries. International Business Review. 21(2): 167-179.

Hardy, J., Sass, M. and Pollakova-Fifekova, M. (2011). Impacts of horizontal and vertical foreign investment in business services: the experience of Hungary, Slovakia and the Czech Republic. European Urban and Regional Studies. 18(4): 427-443.

Havránek, T. and Iršová, Z. (2011). Estimating Vertical Spillovers from FDI: Why Results vary and what the True Effect is. Journal of International Economics. 85(2): 234-244.

Helpman, E., Melitz, M.J. and Yeaple, S.R. (2004). Exports versus FDI with Heterogenous Firms. American Economic Review. 94(1): 300-316. 
Hoekman, B. and A. Mattoo (2008). Services trade and growth. World Bank Policy Research Working Paper 4030.

IMF (2009). Balance of payments and international investment position manual. 6th ed. Washington, D.C.: IMF.

Iršová, Z. and Havránek, T. (2013). Determinants of Horizontal Spillovers from FDI: Evidence from a Large Meta-Analysis. World Development. 42(c): 1-15.

Javorcik, B. S. (2004). Does foreign direct investment increase the productivity of domestic firms? In search of spillovers through backward linkages. The American Economic Review. 94(3): 605-627.

Javorcik, B. S. (2007). Foreign direct investment and international technology transfer: What do we know? What would we like to know? The World Bank and CEPR Working Paper. Washington, DC: The World Bank.

Javorcik, B. S. and Spatareanu, M. (2011). Does it matter where you come from? Vertical spillovers from foreign direct investment and the origin of investors. Journal of Development Economics. 96(1): 126-138.

Javorcik, B. S., and Spatareanu, M. (2008). To share or not to share: Does local participation matter for spillovers from foreign direct investment? Journal of Development Economics. 85(12): 194-217.

Jindra, B. (2006). Theories and review of the latest research on the effects of FDI in CEE. In J. Stephan (Ed.), Technology transfer via foreign direct investment in Central and Eastern Europe - Theory, method of research - Empirical evidence. Houndsmill Basingstoke PalgraveMacMillan.

Jindra, B. and Rojec, M. (2014). Knowledge Spillovers from FDI and Positioning of CEECs in Times of a Global Shift in Production and Innovation - A Policy Perspective. GRINCOH Working Paper Series No. 214.

Jindra, B., Giroud, A. and Scott-Kennel, J. (2009). Subsidiary roles, vertical linkages and economic development: Lessons from transition economies. Journal of World Business. 44(2): 167-179.

Jude, C. (2016). Technology Spillovers from FDI. Evidence on the Intensity of Different Spillover Channels. World Economy. 39(12): 1847-1973.

Kolasa, M. (2008). How does FDI inflow affect productivity of domestic firms? The role of horizontal and vertical spillovers, absorptive capacity and competition. Journal of International Trade and Economic Development. 17(1): 155-173.

Konings, J. (2001), The effects of foreign direct investment on domestic firms: evidence from firm-level panel data in emerging economies. Economics of Transition. 9(3): 619-633.

Kouizumi, T. and Kopecky, K. J. (1977). Economic Growth, Capital Movements and the International Transfer of Technical Knowledge. Journal of International Economics. 7(1): 4565 . 
Kox, H.L.M. and Rubalcaba, L. (2007). Analysing the contribution of business services to European economic growth. MPRA Paper No.3750, University Library of Munich, Germany.

Landry, R., Amara, N. and Doloreux, D. (2012). Knowledge-exchange strategies between KIBS firms and their clients. The Service Industries Journal. 32(2). p. 291-320.

Levinsohn, J. and Petrin, A. (2003). Estimating Production Functions Using Inputs to Control for Unobservables. Review of Economic Studies. 70(2): 317-342.

Mariotti, S. Mutinelli, M., Nicolini, M. and Piscitello, L. (2015). Productivity Spillovers from Foreign Multinational Enterprises to Domestic Manufacturing Firms: To What Extent Does Spatial Proximity Matter? Regional Studies. 49(10): 1639-1653.

Mariotti, S., Nicolini, M. and Piscitello, L. (2013). Vertical linkages between foreign MNEs in service sectors and local manufacturing firms. Structural Change and Economic Dynamics. (25): 133-145.

Markusen, J. and Venables, A. (1999). Foreign Direct Investment as a Catalyst for Industrial Development. European Economic Review. 43(2): 335-356.

Markusen, J. R. and Trofimenko, N. (2009). Teaching locals new tricks: Foreign experts as a channel of knowledge transfers. Journal of Development Economics. 88(1): 120-131.

Marrocu, E., Paci, R. and Pontis, M. (2012). Intangible capital and firms' productivity. Industrial and Corporate Change .21(2): 377-402.

Marschak, J. and Andrews, W. H. (1944). Random Simultaneous Equations and the Theory of production. Econometrica. 12(3/4): 143-205.

Masso, J. and Vahter, P. (2012). The link between innovation and productivity in Estonia's services sector. The Services Trade Journal. 32(16): 2527-2541.

Mas-Verdu, F., Wensley, A., Alba, M., and Garcia, J. M. (2011). How much does KIBS contribute to the generation and diffusion of innovation? Service Business. 5(3): 195-212

Merlevede, B., Schoors, K. and Spatareanu, M. (2014). FDI Spillovers and Time since Foreign Entry. World Development. (56): 108-126.

Miles I. (1994). Knowledge-Intensive Business Services: their role as users, carriers and sources of innovation. Manchester: Prest.

Miles, I. (2005). Innovation in services. In: J. Fagerberg, D. Mowery, R. Nelson (eds). The Oxford Handbook of Innovation, pp. 433-458. Oxford: Oxford University Press.

Miozzo M. and Grimshaw, D.P. (2008). Service multinationals and forward linkages with client firms: The case of IT outsourcing in Argentina and Brazil. International Business Review. 17(1): 8-27. 
Miozzo, M., Yamin, M. and Ghauri, P. N. (2012). Strategy and structure of service multinationals and their impact on linkages with local firms. The Service Industries Journal. 23(7): 1171-1191.

Mirodout, S. (2006). The Linkages between Open Services Markets and Technology Transfer. OECD Trade Policy Papers No. 29, OECD Publishing.

Myant, M. and Drahokoupil, J. (2010). Transition Economies: Political Economy in Russia, Eastern Europe, and Central Asia. Hoboken: Wiley-Blackwell

Narula, R. and Marin, A. (2003). FDI Spillovers, Absorptive Capacities and Human Capital Development: Evidence from Argentina. Maastricht Economic Research Institute on Innovation and Technology Working Paper No. 16.

Nelson, R. and Winter, S.G. (1982). An Evolutionary Theory of Economic Change. Cambridge: Belknap Press/Harvard University Press.

Newman, C., Rand, J., Talbot, T. and Trap, F. (2015). Technology transfers, foreign investment and productivity spillovers. European Economic Review. (76): 168-187.

OECD (2005). A Policy Framework for Investment: Investment Promotion and Facilitation. OECD Conference Investment for Development: Making it Happen, 25-27 October, Rio de Janeiro.

OECD (2007). Science, Technology and Industry Scoreboard. Annex 1. Paris: Directorate for Science, Technology, and Industry.

Olley, S.G. and Pakes, A. (1996). The dynamics of productivity in the telecommunications equipment industry. Econometrica. 64(6). p. 1263-1297.

Oulton, N. (2001). Must the growth rate decline? Baumol's unbalanced growth revisited. Oxford Economic Papers. 53(4): 605-627.

Petrin, A. and Levinsohn, J. (2012). Measuring aggregate productivity growth using plant-level data. The RAND Journal of Economics. 43(4): 705-725.

Petrin, A., White, K.T. and Weiter. J. (2011). The impact of plant-level resource reallocations and technical progress on US macroeconomic growth. Review of Economic Dynamics. 14(1): $3-26$.

Ragoussis, A. (2014). Exports and Knowledge-Based Capital: New evidence using micro-data. Mimeo.

Ripolles Melia, M., Blesa Perez, A., and Rolg Dobon, S. (2010). The influence of innovation orientation on the internationalization of SMEs in the service sector. The Service Industries Journal. 30(5): 777-791.

Rodríguez-Clare, A. (1996). Multinationals, Linkages, and Economic Development. American Economic Review. 86(4): 852-873.

Roodman, D. (2009). A note on the theme of too many instruments. Oxford Bulletin of Economics and Statistics. 71(1): 135-158. 
Rugraff, E. (2006). Export-oriented multinationals and the quality of international specialisation in Central European countries. The European Journal of Development Research, 18(4): 642-660.

Sanchez-Sellero, P., Rosell-Marinez, J. and Garcia-Vasquez, J. M. (2014). Absorptive capacity from foreign direct investment in Spanish manufacturing firms. International Business Review. 23: 429-439.

Sanfilippo, M. (2015). FDI from emerging markets and the productivity gap-An analysis on affiliates of BRICS EMNEs in Europe. International Business Review, 24(4): 665-676.

Sass, M. (2008). Szolgáltatások relokációja - európai folyamatok [Relocation of services European developments]. Európai Tükör. 13(7-8): 85-100.

Schoors, K. and Merlevede, B. (2007). FDI and the Consequences: Towards more complete capture of spillover effects. William Davidson Institute Working Paper No. 886.

Shearmur, R. and Doloreux, D. (2008). Urban hierarchy or local buzz? High-order producer service and (or) knowledge-intensive business service location in Canada, 1991-2001. Professional Geographer. 60: 333-355.

Shearmur, R., Doloreux, D. and Laperriere, A. (2015). Is the degree of internationalization associated with the use of knowledge intensive services or with innovation? International Business Review. 24(3): 457-465.

Shepotylo, O. and Vakhitov, V. (2015). Services Liberalization and Productivity of Manufacturing Firms: Evidence from Ukraine. Economics of Transition. 23(1): 1-44.

Smeets, R. (2008). Collecting the Pieces of the FDI Knowledge Spillovers Puzzle. World Bank Research Observer. 23(2): 107-138.

Smeets, R. and de Vall, A. (2016). Intellectual Property Rights and the productivity effects of MNE affiliates on host-country firms. International Business Review, 25(1): 419-434.

Spencer, J.W. (2008). The impact of multinational enterprise strategy on indigenous enterprises: Horizontal spillovers and crowding out effects in developing countries. Academy of Management Review. 33(2). p. 341-361.

Syverson, C. (2011). What Determines Productivity. Journal of Economic Literature. 49(2): 326-265.

Teece, D. J. (2011). Dynamic Capabilities and Strategic Management: Organizing for Innovation and Growth. Oxford: Oxford University Press

Tether, B. S. and Hipp, C. (2002). Knowledge intensive, technical and other services: Patterns of competitiveness and innovation compared. Technology Analysis \& Strategic Management.14(2): 163-182.

UNCTAD (2004). World investment report: The shift towards services. Geneva: United nations. 
UNCTAD (2008). World Investment Report: Transnational corporations and the infrastructure challenge. Geneva: United Nations.

UNCTAD (2014). World Investment Report: Investing in the SDGs: An Action Plan. Geneva: United Nations.

Wagner, J. (2012). Average wage, qualification of the workforce and export performance in German enterprises. Journal for Labour Market Research. 45(2): 161-170.

Wang, C., Clegg, J. and Kafouros, M. (2009). Country-of-origin effects of foreign direct investment: An industry level analysis. Management International Review. 49(2): 179-198.

Wang, C., Deng, Z., Kafouros, M.I. and Chen, Y. (2012). Reconceptualizing the spillover effects of foreign direct investment: A process-dependent approach. International Business Review. 21: 452-464.

Wang, J. and Blomström, M. (1992). Foreign Investment and Technology Transfer: a Simple Model. European Economic Review. 36(1): 137-155.

Wooldridge, J.M. (2009). On estimating firm-level production functions using proxy variables to control for unobservables. Economics Letters. 104(3): 112-114.

Zanfei, A. (2012). Effects, Not Externalities. European Journal of Development Research. 24(1): 8-14. 


\section{APPENDIX}

Table A1. Output of Cobb-Douglas value added production function across countries and industries based on Wooldridge (2009) estimator

\begin{tabular}{|c|c|c|c|c|c|c|c|c|c|c|c|c|}
\hline \multirow[b]{2}{*}{ NACE GROUP } & \multicolumn{4}{|c|}{ Czech Republic } & \multicolumn{4}{|c|}{ Estonia } & \multicolumn{4}{|c|}{ Hungary } \\
\hline & labour & capital & Observations & Returns to scale & labour & capital & Observations & Returns to scale & labour & capital & Observations & Returns to scale \\
\hline 1516 & $0.518 * * *$ & $0.172 * * *$ & 3,740 & $0.69^{* * *}$ & $0.497 * * *$ & $0.140 * * *$ & 1,013 & $0.637 * * *$ & $0.538 * * *$ & $0.192 *$ & 496 & $0.73 * *$ \\
\hline 1718 & $0.554 * * *$ & $0.154 * * *$ & 1,964 & $0.708 * * *$ & $0.695^{* * *}$ & 0.042 & 1,190 & $0.737 * * *$ & $0.732 * * *$ & 0.18 & 107 & 0.91 \\
\hline 19 & $0.652 * * *$ & $0.521 * * *$ & 274 & 1.173 & $0.596^{* * *}$ & 0.0193 & 123 & $0.615 * * *$ & $0.732 * * *$ & 0.18 & 107 & 0.91 \\
\hline 20 & $0.554 * * *$ & $0.145^{* * *}$ & 2,547 & $0.699 * * *$ & $0.520^{* * *}$ & $0.221 * * *$ & 2,000 & $0.741 * * *$ & 0.413 & 0.288 & 39 & 0.7 \\
\hline 2122 & $0.725^{* * *}$ & $0.102 * * *$ & 3,127 & $0.827 * * *$ & $0.556^{* * *}$ & $0.104 * * *$ & 1,298 & $0.66^{* * *}$ & $0.848 * * *$ & 0.109 & 196 & 0.96 \\
\hline 2324 & $0.421 * * *$ & $0.107 * *$ & 1,315 & $0.528 * * *$ & $0.776^{* * *}$ & 0.0631 & 122 & 0.839 & $0.535 * * *$ & 0.0933 & 156 & $0.63^{* * *}$ \\
\hline 25 & $0.490 * * *$ & $0.166^{* * *}$ & 2,990 & $0.656^{* * *}$ & $0.693 * * *$ & $0.140 * * *$ & 387 & $0.833^{* *}$ & $0.550 * * *$ & $0.283^{* *}$ & 298 & 0.83 \\
\hline 26 & $0.353^{* * *}$ & $0.102 * * *$ & 1,864 & $0.455^{* * *}$ & $0.565^{* * *}$ & $0.269 * * *$ & 353 & $0.835^{*}$ & $0.487 * * *$ & $0.292^{* *}$ & 141 & 0.78 \\
\hline 2728 & $0.570 * * *$ & $0.209 * * *$ & 9,565 & $0.779 * * *$ & $0.732 * * *$ & $0.154 * * *$ & 1,927 & $0.886^{* * *}$ & $0.609 * * *$ & $0.348 * * *$ & 474 & 0.96 \\
\hline 29 & $0.550 * * *$ & $0.138 * * *$ & 6,568 & $0.689^{* * *}$ & $0.578 * * *$ & $0.178 * * *$ & 706 & $0.757 * * *$ & $0.541 * * *$ & 0.243 & 281 & 0.78 \\
\hline 3033 & $0.567 * * *$ & $0.169^{* * *}$ & 5,080 & $0.736 * * *$ & $0.657^{* * *}$ & $0.178^{* * *}$ & 533 & $0.835^{* * * *}$ & $0.726 * * *$ & 0.218 & 263 & 0.94 \\
\hline 3435 & $0.482 * * *$ & $0.239 * * *$ & 1,278 & $0.721 * * *$ & $0.719 * * *$ & $0.114 * *$ & 372 & 0.832 & $0.676^{* * * *}$ & $0.385^{* * *}$ & 128 & 1.06 \\
\hline 3637 & $0.448^{* * *}$ & $0.199 * * *$ & 2,556 & $0.647 * * *$ & $0.529 * * *$ & $0.182 * * *$ & 1,482 & $0.711^{* * *} *$ & $0.789 * * *$ & -0.00057 & 114 & 0.79 \\
\hline
\end{tabular}




\begin{tabular}{|c|c|c|c|c|c|c|c|c|}
\hline \multirow[b]{2}{*}{ NACE GROUP } & \multicolumn{4}{|c|}{ Slovakia } & \multicolumn{4}{|c|}{ Slovenia } \\
\hline & labour & capital & Observations & Returns to scale & labour & capital & Observations & Returns to scale \\
\hline 1516 & $0.366^{* * * *}$ & $0.322 * * *$ & 967 & $0.69^{* * *}$ & $0.582 * * *$ & 0.0508 & 207 & $0.63 * * *$ \\
\hline 1718 & $0.503 * * *$ & $0.246 * * *$ & 440 & $0.75^{* * *}$ & $0.548^{* * * *}$ & -0.0218 & 176 & $0.52 * * *$ \\
\hline 19 & $0.379 * * *$ & $0.342 *$ & 105 & 0.72 & $0.548^{* * * *}$ & -0.0218 & 176 & $0.52 * * *$ \\
\hline 20 & $0.272 * * *$ & $0.305 * * *$ & 497 & $0.58 * * *$ & $0.346 * * *$ & $0.169 * * *$ & 219 & $0.51 * * *$ \\
\hline 2122 & $0.577 * * *$ & $0.177 * *$ & 525 & $0.75 * *$ & $0.928 * * *$ & $0.0942 * *$ & 558 & 1.02 \\
\hline 2324 & $0.160 * *$ & $0.218^{*}$ & 249 & $0.38^{* * *}$ & $0.484 * * *$ & $-0.161 * * *$ & 53 & $0.32 * * *$ \\
\hline 25 & $0.384 * * *$ & $0.324 * * *$ & 564 & $0.71 * * *$ & $0.431^{* * * *}$ & $0.147 *$ & 364 & $0.57 * * *$ \\
\hline 26 & $0.151 * * *$ & $0.603 * * *$ & 447 & $0.75 * *$ & $0.559^{* * * *}$ & -0.0113 & 125 & $0.54 * * *$ \\
\hline 2728 & $0.367 * * *$ & $0.403 * * *$ & 1,680 & $0.77 * * *$ & $0.595 * * *$ & $0.228 * * *$ & 1,163 & $0.82 * * *$ \\
\hline 29 & $0.341 * * *$ & $0.322 * * *$ & 1,185 & $0.66^{* * *}$ & $0.543^{* * * *}$ & $0.147 * * *$ & 403 & $0.69 * * *$ \\
\hline 3033 & $0.396 * * *$ & $0.267 * * *$ & 697 & $0.66 * * *$ & $0.445^{* * * *}$ & $0.149 * *$ & 283 & $0.59 * * *$ \\
\hline 3435 & $0.197 * * *$ & $0.308 * * *$ & 291 & $0.51 * * *$ & $0.400^{* * * *}$ & $0.385^{* * *}$ & 69 & $0.78^{* *}$ \\
\hline 3637 & $0.381 * * *$ & $0.381 * * *$ & 521 & $0.76 * *$ & $0.237 * * *$ & $0.156^{* *}$ & 308 & $0.39 * * *$ \\
\hline
\end{tabular}

Note: Due to insufficient number of observations in industry 19, the latter was combined with industry 17 and 18 in Hungary and Slovenia.

Table A2. Correlation of TFP estimates across different estimators

\begin{tabular}{|c|c|c|c|c|c|c|c|c|c|c|c|c|c|c|}
\hline & $\begin{array}{c}\text { Czech } \\
\text { Republic }\end{array}$ & & & & & Estonia & & & & & Hungary & & & \\
\hline & WLP & LP & OLS & GMM & & WLP & LP & OLS & GMM & & WLP & LP & OLS & GMM \\
\hline WLP & 1.00 & & & & WLP & 1.00 & & & & WLP & 1.00 & & & \\
\hline LP & 1.00 & 1.00 & & & LP & 1.00 & 1.00 & & & LP & 0.94 & 1.00 & & \\
\hline OLS & 0.85 & 0.84 & 1.00 & & OLS & 0.89 & 0.88 & 1.00 & & OLS & 0.50 & 0.49 & 1.00 & \\
\hline \multirow[t]{3}{*}{ GMM } & 0.83 & 0.84 & 0.74 & 1.00 & GMM & 0.82 & 0.81 & 0.88 & 1.00 & GMM & 0.63 & 0.58 & 0.08 & 1.00 \\
\hline & Slovakia & & & & & lovenia & & & & & & & & \\
\hline & $\overline{\text { WLP }}$ & $\overline{L P}$ & $\overline{\text { OLS }}$ & GMM & & WLP & $\overline{L P}$ & $\overline{\text { OLS }}$ & GMM & & & & & \\
\hline WLP & 1.00 & & & & WLP & 1.00 & & & & & & & & \\
\hline LP & 0.99 & 1.00 & & & LP & 0.98 & 1.00 & & & & & & & \\
\hline OLS & 0.88 & 0.87 & 1.00 & & OLS & 0.79 & 0.80 & 1.00 & & & & & & \\
\hline GMM & 0.78 & 0.81 & 0.69 & 1.00 & GMM & 0.64 & 0.57 & 0.51 & 1.00 & & & & & \\
\hline
\end{tabular}


Table A3. Representativeness of Amadeus database versus Eurostat SBS

\begin{tabular}{|c|c|c|c|c|c|c|}
\hline \multirow{2}{*}{\multicolumn{2}{|c|}{$\begin{array}{c}\text { SBS 2002-2010 (average) } \\
\text { \# firms }\end{array}$}} & \multicolumn{5}{|c|}{ Amadeus as a share of SBS } \\
\hline & & \# employees & turnover & \#firms with employees & \#firms with employees and turnover & $\begin{array}{l}\text { \#firms with employees, value } \\
\text { added and tangible fixed assets }\end{array}$ \\
\hline Czech Republic & 884,842 & $64 \%$ & $80 \%$ & $7 \%$ & $5.1 \%$ & $3.9 \%$ \\
\hline Estonia & 42,463 & $79 \%$ & $86 \%$ & $60.1 \%$ & $59.0 \%$ & $35.5 \%$ \\
\hline Hungary & 556,195 & $28 \%$ & $81 \%$ & $5.5 \%$ & $5.2 \%$ & $0.5 \%$ \\
\hline Slovakia & 47,624 & $53 \%$ & $55 \%$ & $43 \%$ & $20.8 \%$ & $17.7 \%$ \\
\hline Slovenia & 98,568 & $12 \%$ & $11 \%$ & $3.9 \%$ & $3.2 \%$ & $3.0 \%$ \\
\hline
\end{tabular}

Note: Data on the number of firms and turnover in year 2010 for Czech Republic are not available for most industries in SBS, therefore the comparison is made up until 2009. Similarly, there was a large increase in the number of firms in SBS for Slovakia starting from year 2010 so in order to reduce possible misrepresentation of the data, we limit the comparison up until 2009 for shares involving the number of firms.

\section{Table A4. Comparison of firm size distribution between Eeurostat SBS and Amadeus database}

\begin{tabular}{|c|c|c|c|c|c|c|c|c|c|c|c|c|c|c|c|}
\hline & \multicolumn{5}{|c|}{$\begin{array}{c}\text { SBS } \\
(2002-2010 \text { average })\end{array}$} & \multicolumn{6}{|c|}{$\begin{array}{l}\text { Amadeus (firms with employment) } \\
\text { (2002-2010 average) }\end{array}$} & \multicolumn{4}{|c|}{$\begin{array}{c}\text { Amadeus (firms with TFP) } \\
\text { (2002-2010 average) }\end{array}$} \\
\hline & $1-9$ & 10-19 & $20-49$ & $50-249$ & $>250$ & $1-9$ & $10-19$ & $20-49$ & 50-249 & $>250$ & $1-9$ & $10-19$ & $20-49$ & 50-249 & $>250$ \\
\hline Czech Republic & $95.3 \%$ & $2.4 \%$ & $1.4 \%$ & $0.8 \%$ & $0.2 \%$ & $68.2 \%$ & $12.9 \%$ & $9.5 \%$ & $7.7 \%$ & $1.8 \%$ & $46.2 \%$ & $19.2 \%$ & $16.6 \%$ & $14.5 \%$ & $3.5 \%$ \\
\hline Estonia & $84.0 \%$ & $8.0 \%$ & $5.1 \%$ & $2.6 \%$ & $0.4 \%$ & $79.3 \%$ & $10.2 \%$ & $6.7 \%$ & $3.4 \%$ & $0.4 \%$ & $69.5 \%$ & $15.0 \%$ & $10.1 \%$ & $4.8 \%$ & $0.6 \%$ \\
\hline Hungary & $94.6 \%$ & $3.0 \%$ & $1.5 \%$ & $0.8 \%$ & $0.1 \%$ & $78.8 \%$ & $9.6 \%$ & $6.5 \%$ & $4.1 \%$ & $1.1 \%$ & $7.0 \%$ & $10.8 \%$ & $24.1 \%$ & $41.6 \%$ & $16.5 \%$ \\
\hline Slovakia & $84.8 \%$ & $9.4 \%$ & $2.8 \%$ & $2.4 \%$ & $0.6 \%$ & $77.8 \%$ & $10.9 \%$ & $4.9 \%$ & $5.1 \%$ & $1.4 \%$ & $67.7 \%$ & $14.7 \%$ & $10.5 \%$ & $6.1 \%$ & $1.0 \%$ \\
\hline Slovenia & $92.9 \%$ & $3.6 \%$ & $2.0 \%$ & $1.2 \%$ & $0.3 \%$ & $72.3 \%$ & $13.3 \%$ & $8.7 \%$ & $4.9 \%$ & $0.8 \%$ & $41.0 \%$ & $23.1 \%$ & $13.3 \%$ & $17.7 \%$ & $5.0 \%$ \\
\hline
\end{tabular}


Table A5. Number of observations (domestic firms only) used in TFP estimation

\begin{tabular}{lccccc}
\hline & Czech Republic & Estonia & Hungary & Slovakia & Slovenia \\
\hline High tech manufacturing & 3,439 & 424 & 338 & 493 & 192 \\
Medium high tech manufacturing & 16,027 & 1,596 & 966 & 2,983 & 869 \\
Medium low tech manufacturing & 20,029 & 3,784 & 1,448 & 4,036 & 2,247 \\
Low tech manufacturing & 19,762 & 9,228 & 1,539 & 4,478 & 1,997 \\
\hline Total & $\mathbf{5 9 , 2 5 7}$ & $\mathbf{1 5 , 0 3 2}$ & $\mathbf{4 , 2 9 1}$ & $\mathbf{1 1 , 9 9 0}$ & $\mathbf{5 , 3 0 5}$ \\
\hline
\end{tabular}

Table A6. Number of firms per industry and country over the 2002-2010 period in the original sample

\begin{tabular}{|c|c|c|c|c|c|c|c|c|c|c|}
\hline & \multicolumn{2}{|c|}{ Czech Republic } & \multicolumn{2}{|c|}{ Estonia } & \multicolumn{2}{|c|}{ Hungary } & \multicolumn{2}{|c|}{ Slovakia } & \multicolumn{2}{|c|}{ Slovenia } \\
\hline & Domestic & Foreign & Domestic & Foreign & Domestic & Foreign & Domestic & Foreign & Domestic & Foreign \\
\hline Construction & 134,352 & 1,119 & 43,096 & 1,263 & 88,475 & 145 & 71,102 & 199 & 15,259 & 55 \\
\hline High tech manufacturing & 2,032 & 170 & 241 & 60 & 2,642 & 27 & 1,231 & 42 & 280 & 4 \\
\hline Medium high tech manufacturing & 9,400 & 733 & 837 & 145 & 5,929 & 86 & 3,643 & 212 & 1,086 & 25 \\
\hline Medium low tech manufacturing & 14,997 & 838 & 1,914 & 222 & 9,981 & 118 & 7,605 & 226 & 2,278 & 22 \\
\hline Low tech manufacturing & 21,025 & 635 & 4,420 & 390 & 20,939 & 99 & 12,865 & 184 & 3,323 & 28 \\
\hline High knowledge intensive services & 7,749 & 482 & 5,456 & 527 & 26,040 & 68 & 5,372 & 102 & 3,758 & 66 \\
\hline Market knowledge intensive services & 109,401 & 6,309 & 25,157 & 2,212 & 105,204 & 349 & 41,912 & 496 & 15,649 & 97 \\
\hline Less knowledge intensive services & 155,220 & 5,540 & 25,872 & 2,323 & 118,056 & 490 & 90,932 & 1,357 & 20,602 & 386 \\
\hline Total & 454,176 & 15,826 & 106,993 & 7,142 & 377,266 & 1,382 & 234,662 & 2,818 & 62,235 & 683 \\
\hline
\end{tabular}


Table A7a. Correlation matrix - Czech Republic

\begin{tabular}{|c|c|c|c|c|c|c|c|c|c|c|c|c|}
\hline TFP & $\begin{array}{l}\text { TFP } \\
1.00\end{array}$ & Horizontal & $\begin{array}{l}\text { Manufacturing } \\
\text { backward }\end{array}$ & $\begin{array}{l}\text { Manufacturing } \\
\text { forward }\end{array}$ & $\begin{array}{l}\text { Services } \\
\text { backward }\end{array}$ & $\begin{array}{l}\text { Services } \\
\text { forward }\end{array}$ & Demand & HHI & Age & Size & $\begin{array}{l}\text { Average } \\
\text { wage }\end{array}$ & Intangibles \\
\hline Horizontal & 0.12 & 1.00 & & & & & & & & & & \\
\hline $\begin{array}{l}\text { Manufacturing } \\
\text { backward }\end{array}$ & 0.04 & 0.14 & 1.00 & & & & & & & & & \\
\hline $\begin{array}{l}\text { Manufacturing } \\
\text { forward }\end{array}$ & 0.16 & 0.22 & 0.40 & 1.00 & & & & & & & & \\
\hline $\begin{array}{l}\text { Services } \\
\text { backward }\end{array}$ & -0.02 & 0.19 & -0.26 & 0.09 & 1.00 & & & & & & & \\
\hline $\begin{array}{l}\text { Services } \\
\text { forward }\end{array}$ & 0.06 & 0.37 & 0.48 & 0.31 & 0.33 & 1.00 & & & & & & \\
\hline Demand & 0.06 & 0.28 & 0.43 & -0.04 & -0.37 & -0.12 & 1.00 & & & & & \\
\hline $\mathrm{HHI}$ & 0.02 & 0.17 & -0.04 & -0.05 & -0.01 & -0.01 & 0.04 & 1.00 & & & & \\
\hline Age & 0.07 & 0.12 & 0.05 & 0.11 & 0.08 & 0.19 & -0.09 & -0.02 & 1.00 & & & \\
\hline Size & 0.57 & 0.13 & -0.01 & 0.09 & -0.01 & 0.02 & 0.02 & 0.08 & 0.23 & 1.00 & & \\
\hline Average wage & 0.59 & 0.17 & 0.11 & 0.18 & 0.04 & 0.13 & 0.11 & -0.01 & 0.07 & 0.30 & 1.00 & \\
\hline Intangibles & -0.04 & -0.04 & 0.00 & 0.04 & 0.01 & -0.02 & 0.02 & 0.00 & -0.19 & -0.40 & -0.03 & 1.00 \\
\hline
\end{tabular}

Table A7b. Correlation matrix - Estonia

\begin{tabular}{|c|c|c|c|c|c|c|c|c|c|c|c|c|}
\hline & TFP & Horizontal & $\begin{array}{c}\text { Manufacturing } \\
\text { backward }\end{array}$ & $\begin{array}{l}\text { Manufacturing } \\
\text { forward }\end{array}$ & $\begin{array}{c}\text { Services } \\
\text { backward }\end{array}$ & $\begin{array}{l}\text { Services } \\
\text { forward }\end{array}$ & Demand & HHI & Age & Size & $\begin{array}{c}\text { Average } \\
\text { wage }\end{array}$ & Intangibles \\
\hline TFP & 1.00 & & & & & & & & & & & \\
\hline Horizontal & 0.02 & 1.00 & & & & & & & & & & \\
\hline $\begin{array}{l}\text { Manufacturing } \\
\text { backward }\end{array}$ & 0.02 & 0.41 & 1.00 & & & & & & & & & \\
\hline $\begin{array}{l}\text { Manufacturing } \\
\text { forward }\end{array}$ & 0.01 & 0.12 & 0.53 & 1.00 & & & & & & & & \\
\hline $\begin{array}{l}\text { Services } \\
\text { backward }\end{array}$ & 0.12 & 0.42 & 0.41 & 0.26 & 1.00 & & & & & & & \\
\hline $\begin{array}{l}\text { Services } \\
\text { forward }\end{array}$ & 0.10 & 0.61 & 0.73 & 0.42 & 0.78 & 1.00 & & & & & & \\
\hline Demand & -0.09 & -0.14 & -0.45 & -0.36 & -0.14 & -0.37 & 1.00 & & & & & \\
\hline HHI & 0.02 & 0.44 & 0.14 & -0.08 & 0.13 & 0.20 & -0.14 & 1.00 & & & & \\
\hline
\end{tabular}




\begin{tabular}{|c|c|c|c|c|c|c|c|c|c|c|c|c|}
\hline Age & 0.14 & 0.13 & 0.07 & -0.02 & 0.11 & 0.14 & -0.09 & 0.07 & 1.00 & & & \\
\hline Size & 0.61 & 0.15 & 0.05 & -0.01 & 0.07 & 0.12 & -0.03 & 0.15 & 0.32 & 1.00 & & \\
\hline Average wage & 0.64 & 0.26 & 0.22 & 0.11 & 0.34 & 0.39 & 0.00 & 0.10 & 0.19 & 0.54 & 1.00 & \\
\hline Intangibles & -0.30 & -0.01 & 0.02 & 0.02 & 0.06 & 0.02 & -0.05 & -0.01 & -0.23 & -0.70 & -0.29 & 1.00 \\
\hline
\end{tabular}

Table A7c. Correlation matrix - Hungary

\begin{tabular}{|c|c|c|c|c|c|c|c|c|c|c|c|c|}
\hline TFP & $\begin{array}{l}\text { TFP } \\
1.00\end{array}$ & Horizontal & $\begin{array}{l}\text { Manufacturing } \\
\text { backward }\end{array}$ & $\begin{array}{l}\text { Manufacturing } \\
\text { forward }\end{array}$ & $\begin{array}{l}\text { Services } \\
\text { backward }\end{array}$ & $\begin{array}{l}\text { Services } \\
\text { forward }\end{array}$ & Demand & $\mathrm{HHI}$ & Age & Size & $\begin{array}{l}\text { Average } \\
\text { wage }\end{array}$ & Intangibles \\
\hline Horizontal & -0.24 & 1.00 & & & & & & & & & & \\
\hline $\begin{array}{l}\text { Manufacturing } \\
\text { backward }\end{array}$ & -0.42 & 0.23 & 1.00 & & & & & & & & & \\
\hline $\begin{array}{l}\text { Manufacturing } \\
\text { forward }\end{array}$ & -0.35 & 0.50 & 0.58 & 1.00 & & & & & & & & \\
\hline $\begin{array}{l}\text { Services } \\
\text { backward }\end{array}$ & 0.01 & -0.06 & -0.08 & -0.21 & 1.00 & & & & & & & \\
\hline $\begin{array}{l}\text { Services } \\
\text { forward }\end{array}$ & -0.34 & 0.25 & 0.50 & 0.50 & 0.48 & 1.00 & & & & & & \\
\hline Demand & -0.03 & -0.08 & 0.20 & 0.01 & -0.18 & -0.02 & 1.00 & & & & & \\
\hline HHI & 0.00 & 0.33 & 0.01 & 0.10 & -0.11 & 0.06 & -0.05 & 1.00 & & & & \\
\hline Age & 0.02 & -0.03 & 0.00 & 0.02 & 0.05 & 0.05 & 0.01 & -0.07 & 1.00 & & & \\
\hline Size & 0.49 & 0.15 & -0.13 & 0.01 & 0.00 & -0.03 & 0.03 & 0.11 & 0.12 & 1.00 & & \\
\hline Average wage & 0.35 & 0.14 & 0.09 & 0.15 & 0.17 & 0.18 & 0.11 & 0.00 & 0.08 & 0.37 & 1.00 & \\
\hline Intangibles & 0.10 & 0.06 & 0.03 & 0.06 & 0.05 & 0.07 & 0.07 & 0.05 & -0.03 & 0.05 & 0.20 & 1.00 \\
\hline
\end{tabular}

Table A7d. Correlation matrix - Slovakia

\begin{tabular}{|c|c|c|c|c|c|c|c|c|c|c|c|c|}
\hline & TFP & Horizontal & $\begin{array}{l}\text { Manufacturing } \\
\text { backward }\end{array}$ & $\begin{array}{l}\text { Manufacturing } \\
\text { forward }\end{array}$ & $\begin{array}{l}\text { Services } \\
\text { backward }\end{array}$ & $\begin{array}{l}\text { Services } \\
\text { forward }\end{array}$ & Demand & HHI & Age & Size & $\begin{array}{l}\text { Average } \\
\text { wage }\end{array}$ & Intangibles \\
\hline TFP & 1.00 & & & & & & & & & & & \\
\hline Horizontal & 0.11 & 1.00 & & & & & & & & & & \\
\hline $\begin{array}{l}\text { Manufacturing } \\
\text { backward }\end{array}$ & -0.11 & 0.22 & 1.00 & & & & & & & & & \\
\hline
\end{tabular}




\begin{tabular}{|c|c|c|c|c|c|c|c|c|c|c|c|c|}
\hline $\begin{array}{l}\text { Manufacturing } \\
\text { forward }\end{array}$ & 0.13 & 0.31 & 0.47 & 1.00 & & & & & & & & \\
\hline $\begin{array}{l}\text { Services } \\
\text { backward }\end{array}$ & 0.14 & 0.22 & 0.21 & 0.48 & 1.00 & & & & & & & \\
\hline $\begin{array}{l}\text { Services } \\
\text { forward }\end{array}$ & -0.05 & 0.29 & 0.47 & 0.42 & 0.58 & 1.00 & & & & & & \\
\hline Demand & -0.08 & 0.01 & 0.15 & 0.03 & -0.22 & 0.10 & 1.00 & & & & & \\
\hline HHI & 0.09 & 0.17 & -0.26 & -0.09 & 0.05 & -0.11 & -0.32 & 1.00 & & & & \\
\hline Age & -0.05 & 0.03 & 0.01 & 0.05 & 0.08 & 0.10 & -0.04 & 0.01 & 1.00 & & & \\
\hline Size & 0.37 & 0.08 & -0.08 & -0.02 & -0.08 & -0.03 & -0.01 & 0.09 & 0.09 & 1.00 & & \\
\hline Average wage & 0.46 & 0.05 & 0.07 & 0.08 & 0.04 & 0.03 & 0.09 & 0.00 & -0.08 & 0.23 & 1.00 & \\
\hline Intangibles & 0.15 & 0.04 & 0.05 & 0.08 & 0.05 & -0.01 & 0.00 & 0.00 & -0.09 & -0.28 & -0.03 & 1.00 \\
\hline
\end{tabular}

Table A7e. Correlation matrix - Slovenia

\begin{tabular}{|c|c|c|c|c|c|c|c|c|c|c|c|c|}
\hline TFP & $\begin{array}{l}\text { TFP } \\
1.00\end{array}$ & Horizontal & $\begin{array}{l}\text { Manufacturing } \\
\text { backward }\end{array}$ & $\begin{array}{l}\text { Manufacturing } \\
\text { forward }\end{array}$ & $\begin{array}{l}\text { Services } \\
\text { backward }\end{array}$ & $\begin{array}{l}\text { Services } \\
\text { forward }\end{array}$ & Demand & HHI & Age & Size & $\begin{array}{l}\text { Average } \\
\text { wage }\end{array}$ & Intangibles \\
\hline Horizontal & 0.04 & 1.00 & & & & & & & & & & \\
\hline $\begin{array}{l}\text { Manufacturing } \\
\text { backward }\end{array}$ & -0.06 & 0.05 & 1.00 & & & & & & & & & \\
\hline $\begin{array}{l}\text { Manufacturing } \\
\text { forward }\end{array}$ & -0.01 & 0.19 & 0.68 & 1.00 & & & & & & & & \\
\hline $\begin{array}{l}\text { Services } \\
\text { backward }\end{array}$ & 0.05 & 0.43 & 0.21 & 0.38 & 1.00 & & & & & & & \\
\hline $\begin{array}{l}\text { Services } \\
\text { forward }\end{array}$ & 0.02 & 0.46 & 0.58 & 0.72 & 0.79 & 1.00 & & & & & & \\
\hline Demand & 0.02 & -0.36 & 0.19 & 0.14 & -0.20 & -0.17 & 1.00 & & & & & \\
\hline HHI & 0.07 & 0.28 & -0.24 & -0.10 & 0.12 & 0.08 & -0.52 & 1.00 & & & & \\
\hline Age & 0.04 & 0.03 & 0.01 & 0.04 & 0.07 & 0.06 & -0.03 & -0.01 & 1.00 & & & \\
\hline Size & 0.55 & 0.10 & -0.03 & 0.03 & 0.05 & 0.07 & -0.07 & 0.12 & 0.23 & 1.00 & & \\
\hline Average wage & 0.56 & 0.14 & 0.14 & 0.17 & 0.21 & 0.25 & -0.01 & 0.01 & 0.11 & 0.41 & 1.00 & \\
\hline Intangibles & 0.07 & 0.05 & -0.03 & -0.03 & 0.03 & 0.01 & -0.09 & 0.11 & -0.13 & -0.24 & -0.03 & 1.00 \\
\hline
\end{tabular}


Figure A1. The share of foreign firms in industry output by country and industry
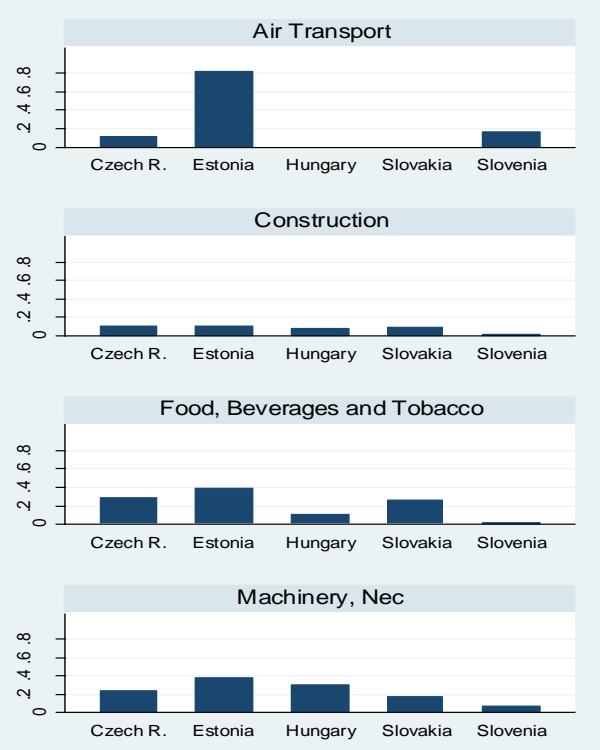

Post and Telecommunications
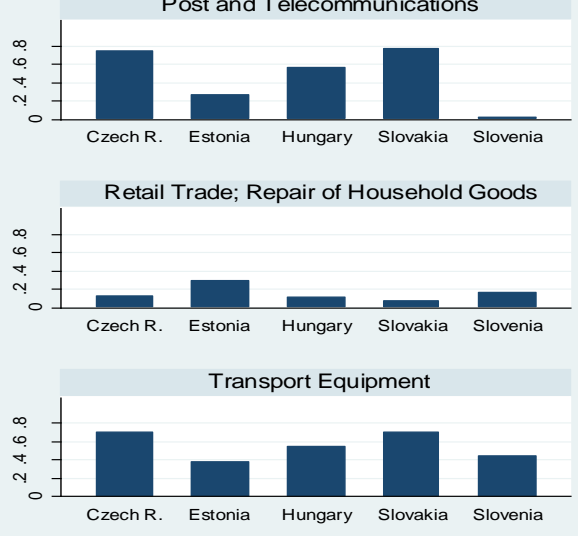

Basic Metals and Fabricated Metal

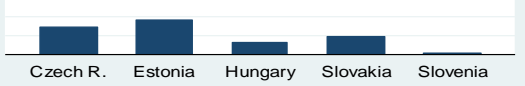

Electrical and Optical Equipment

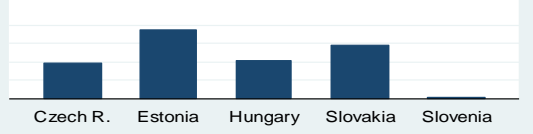

Hotels and Restaurants

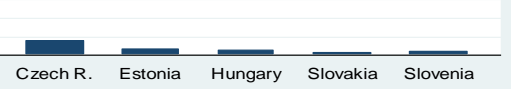

Manufacturing, Nec; Recycling

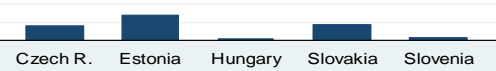

Pulp, Paper, Paper, Printing and Publishing

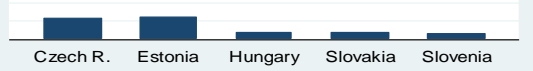

Rubber and Plastics

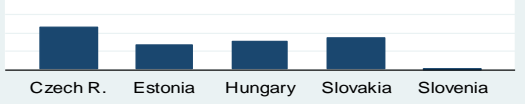

Water Transport

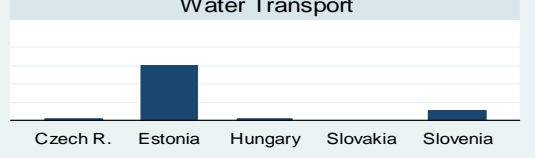

Chemicals and Chemical Products

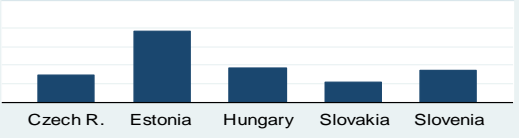

Electricity, Gas and Water Supply

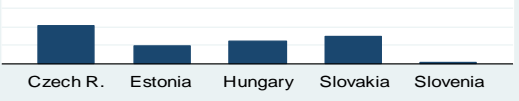

Inland Transport

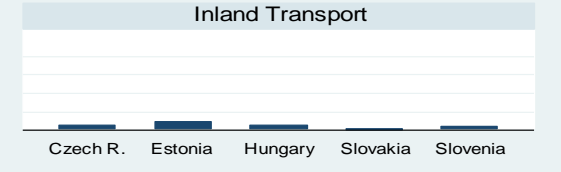

Other Non-Metallic Mineral

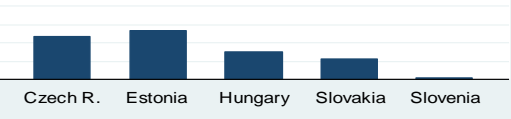

Real Estate Activities

$\overline{\text { Czech R. Estonia }} \overline{\text { Hungary }} \overline{\text { Slovakia }} \overline{\text { Slovenia }}$

Sale, Maintenance and Repair of Motor Vehicles

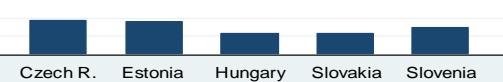

Wholesale Trade and Commission Trade

Czech R. Estonia Hungary Slovakia Slovenia
Coke, Refined Petroleum and Nuclear Fuel

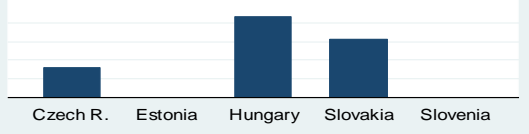

Financial Intermediation

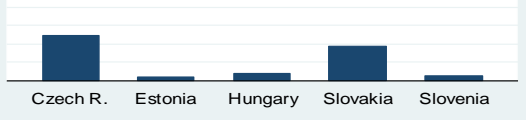

Leather, Leather and Footwear

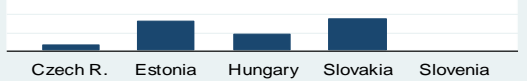

Other Auxiliary Transport and Travel Agencies Activities

Czech R. Estonia Hungary Slovakia Slovenia

Renting of M\&Eq and Other Business Activities

\begin{tabular}{ccc} 
& & \\
\hline Czech R. Estonia Hungary Slovakia Slovenia
\end{tabular}

Textiles and Textile Products

Czech R. Estonia Hungary Slovakia Slovenia

Wood and Products of Wood and Cork

$\begin{array}{lll} & & \\ \text { Czech R. Estonia Hungary Slovakia } & \text { Slovenia }\end{array}$ 
Figure A2. Average size of manufacturing backward and forward linkages across countries and manufacturing industries

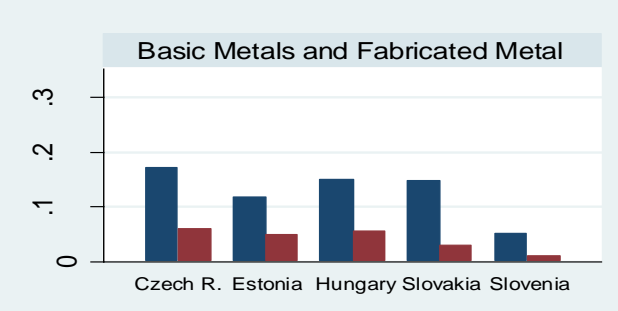

Chemicals and Chemical Products

Coke, Refined Petroleum and Nuclear Fuel

Electrical and Optical Equipment
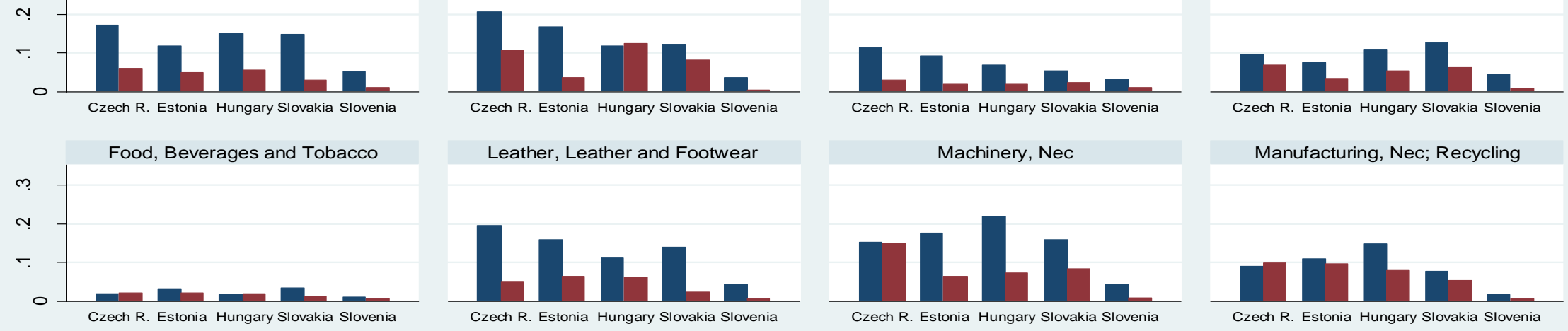

Leather, Leather and Footwear

Machinery, $\mathrm{Nec}$

Manufacturing, Nec; Recycling
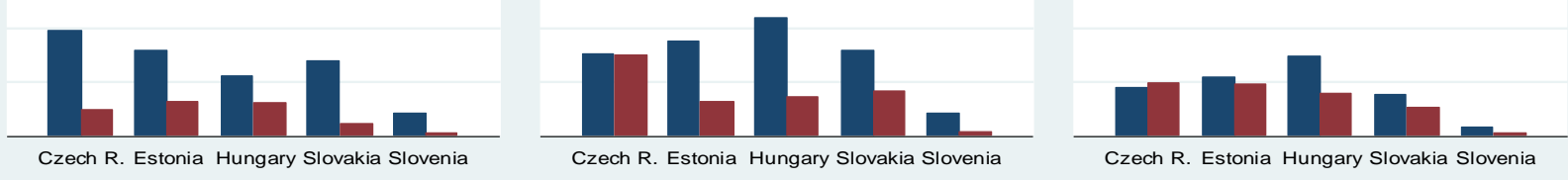

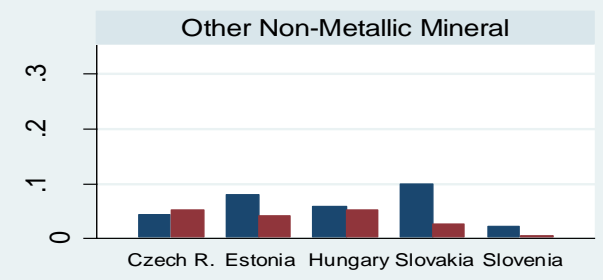

Pulp, Paper, Paper, Printing and Publishing

Rubber and Plastics

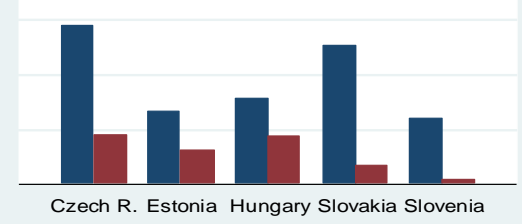

Czech R. Estonia Hungary Slovakia Slovenia

Czech R. Estonia Hungary Slovakia Slovenia

Wood and Products of Wood and Cork
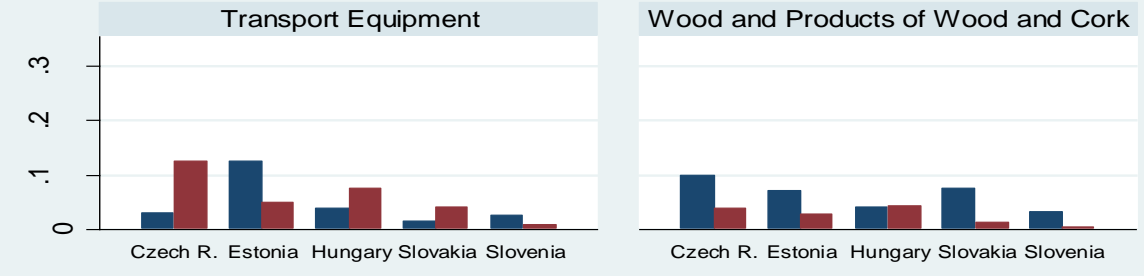

$$
\text { Czech R. Estonia Hungary Slovakia Slovenia }
$$

\begin{tabular}{|l|l|}
\hline backward forward \\
\hline
\end{tabular}


Figure A3. Average size of services backward and forward linkages across countries and manufacturing industries

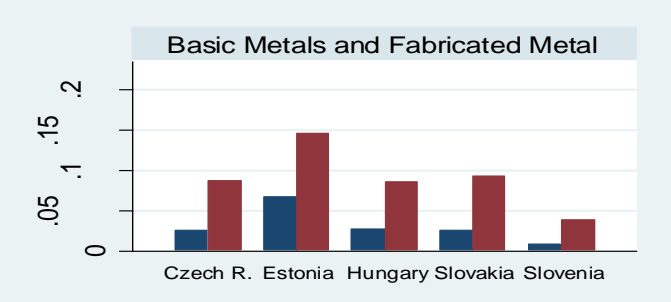

Chemicals and Chemical Products

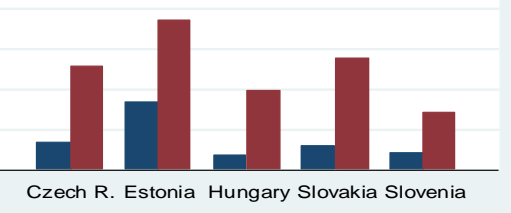

Leather, Leather and Footwear

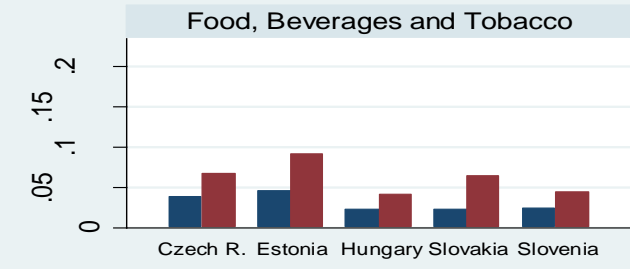

Other Non-Metallic Mineral
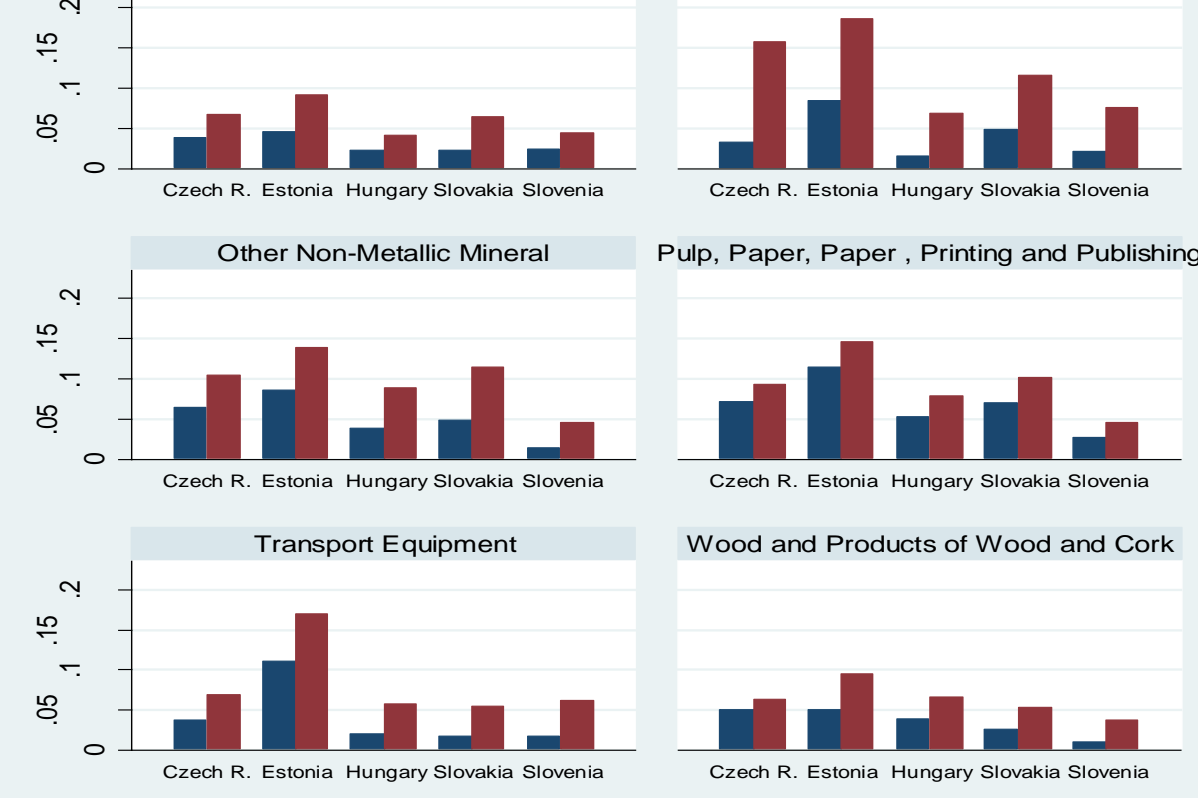

Pulp, Paper, Paper , Printing and Publishing

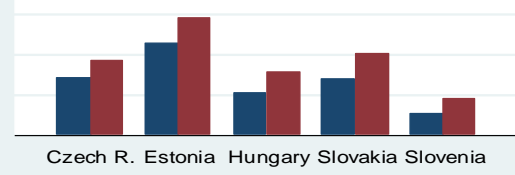

Wood and Products of Wood and Cork

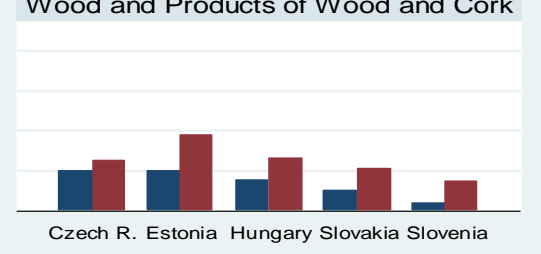

Coke, Refined Petroleum and Nuclear Fuel

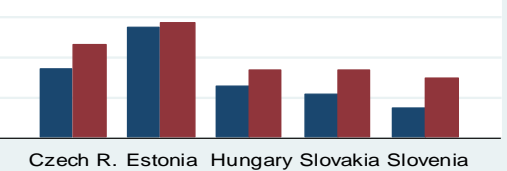

Machinery, Nec

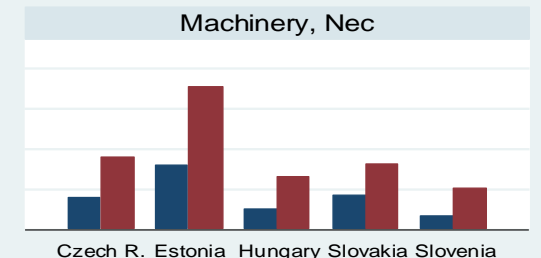

Rubber and Plastics
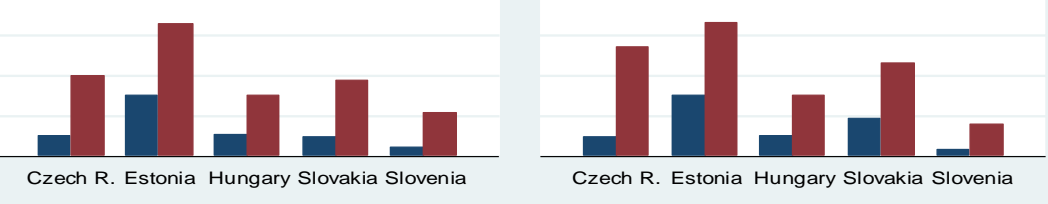

Electrical and Optical Equipment

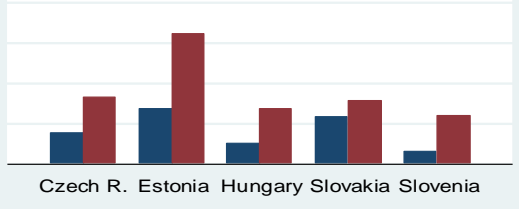

Manufacturing, Nec; Recycling

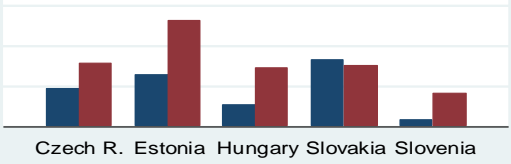

Textiles and Textile Products

backward

forward 